\title{
FREE RANGING HOUSEHOLD DUCKS, AN OVERVIEW ON ENTERIC BACTERIAL AND PARASITIC INFECTIONS
}

\author{
SAMAH EID ${ }^{1}$; SARAH A.A. IBRAHIM ${ }^{2}$ and AMAL S. EL OKSH ${ }^{3}$ \\ ${ }^{1}$ RLQP, Dokki, Bacteriology Department \\ ${ }^{2}$ AHRI, Zagazig, Aquaculture Disease Research Unit \\ ${ }^{3}$ RLQP, Sharkia Branch, Bacteriology Department
}

Received: 30 June 2019; Accepted: 31 July 2019

\begin{abstract}
Ducks are one of the popular household raised poultry in Egypt. Many Egyptian families in Upper and Lower Egypt are adopting the free range raising system where ducks are confined at night and let free at day time for swimming and foraging in the near canals and ponds. Thus, the present study aimed to survey a sample of free ranging ducks (100 birds) and Tilapia zillii fish (100 fish) for bacterial infection (E.coli, Salmonella spp., and Pseudomonas spp.), and for parasitic infection (Clinostomum species, Echinostoma species, ligula intestinalis species and Contraceacum species). E.coli was isolated with prevalence rates (47\%) and (59\%) from ducks, and Tilapia zillii, respectively. Pseudomonas spp. was isolated with prevalence rates of $(15 \%$, and $34 \%)$ from ducks, and Tilapia zillii, respectively. Salmonella spp was isolated with prevalence rates of (25\%, and 9\%) from ducks, and Tilapia zillii, respectively. Studying the prevalence of helminthes infestations revealed the isolation of Echinostoma species with prevalence rates of (13\%, and 17\%) from ducks, and Tilapia zillii, respectively. Clinostomum species was isolated with prevalence rates of $(15 \%$, and $39 \%)$ from ducks, and Tilapia zillii, respectively. Parasitic examination also revealed the isolation of Ligula intestinalis cestode with prevalence rates of (19\%, and 22\%) from ducks, and Tilapia zillii, respectively. Moreover, Contraceacum species was isolated with prevalence rates of (30\%, and $46 \%)$ from ducks, and Tilapia zillii, respectively. Antimicrobial susceptibility patterns of bacterial isolates were studied by disc diffusion and the results revealed the high prevalence of multidrug resistance phenotypes among isolates. Studying genotypic attributes of isolates by PCR revealed the high prevalence of virulence, antimicrobial resistance and biofilm formation genes. The alarming findings highlighted the importance of conducting more detailed monitoring and investigation in the duck / fish interface and to raise public awareness for biosecurity practices to mitigate the imposed public health risk.
\end{abstract}

Key words: Clinostomum species, Contraceacum species, duck, E.coli, Pseudomonas spp, Salmonella spp., and Tilapia zillii.

\section{INTRODUCTION}

Recently great attention has been brought to fish production from natural waters and aquaculture as fish stands for relatively an affordable source of animal protein. Moreover, free ranging water fowls and fish-eating birds are commonly share the habitat in fish communities. Interestingly, scientific studies have reported the detection of an overlap between parasitic and bacterial pathogens among different hosts potentiating their transmission to humans through food. Therefore, transmission of pathogens from fish to fish-eating birds is not far away, consequently raises the importance of studying the potential circulating bacterial and parasitic pathogens in this host range. To enhance the production of safe

Corresponding author: Dr. Amal S. EL Oksh

E-mail address: saidamal19@yahoo.com

Present address: RLQP, Sharkia Branch, Bacteriology Department food recommendations were raised to monitor fish health in aquaculture establishments (Hernandez et al., 1998).

The role of ducks raised in fish farms, as reservoir hosts, has not been adequately investigated. Feeding poultry on snails and fish remains, either intentionally or by discharge of slaughter wastes of ducks and chickens into ponds was identified as one of the risk factors for trematodes infection, (Anh et al., 2010). Furthermore, (Hurlbert et al., 2007) concluded that Pseudomonas, Salmonella and E.coli species are considered major bacterial problems in duck-fish aquaculture development. In the same instances, (Sugita et al., 1994) recorded that these bacteria are widely distributed in fresh water and bottom sediments containing organic materials as well as in the intestinal tract of fish. Furthermore, (Aoki, 1999) reported that infections by these bacterial pathogens may primarily cause massive mortalities, reduce the production and decrease the quality of aquatic 
organisms, moreover, these bacteria may also be encountered as secondary infecting pathogens after primary viral or parasitic infection, as well as causing opportunistic infections after environmental stresses.

Öztürk and Altınok, (2014) concluded that the best way to prevent fish diseases is to prevent both infectious and noninfectious outbreaks, to determine the correct diagnosis, and to apply economically acceptable treatment.

Thus, the present study aimed to investigate the prevalence of some bacterial and parasitic pathogens implicated in enteric infections of household free ranging ducks and fish that share the same environmental habitat.

\section{MATERIALS AND METHODS}

\section{I- Samples' collection}

One hundred diseased ducks that were raised in free range duck-fish backyards, and one hundred freshly dead harvested fish (Tilapia Zilli) were collected from locations at the bank of Mowase canal branched from Nile River at Zagazig city during the period from July 2018 to February 2019. Samples were transferred to RLQP, Sharkia and AHRI Zagazig laboratories. Bacteriological examinations involved samples from intestine, swabs from skin and gills of collected fish, and internal organs of backyard ducks (liver, trachea, lung, heart, and intestine). Parasitological examinations involved the skin, fins, gills, alimentary tract and body cavity of fish (Tilapia Zilli), and (intestinal contents, buccal cavity and esophagus) of ducks. Samples were left for a few minutes into a petri dish containing saline solution, then opened, scraped and examined under light microscope.

\section{I.A- Bacterial examination}

Isolation of E.coli, salmonella species and Pseudomonas spp were applied according to (Kreig et al., 1984), (ISO /IEC 6579:2017), and (Cheesbrough, 2000), respectively.

\section{I.B- Identification of bacterial isolates}

Salmonella, and E. coli isolates were serotyped according to (Patrick and Francois, 2007), and (MacFaddin, 2000), respectively. Pseudomonas isolates were biotyped according to (Cheesbrough, 2000).

\section{I.C- Parasitic examination}

\section{1- Fixation and staining of parasites:}

Trematodes and cestodes were put between two slides, preserved in $10 \%$ formalin for fixation. Nematodes were fixed by using ethyl alcohol (70\%) directly after collection. Trematodes and cestodes were stained in Alum carmine, immediately after staining, the specimens were washed several times in distilled water. Nematodes gave the best results without staining but cleaning in lacto-phenol. This was done as slowly as possible using a dilute solution of acid alcohol $(1.0 \mathrm{ml}$ conc. HCL in $1000 \mathrm{ml}$ of $70 \%$ alcohol) using ascending grades of ethyl alcohol $(50 \%, 60 \%, 70 \%, 80 \%, 90 \%, 95 \%$, and absolute alcohol). Clove oil was used as a good clearing material for trematodes and cestodes, while lactophenol gave good results as a clearing material with nematodes. Canada balsam for trematodes and cestodes, and polyvol for nematodes were used as mounting materials, (Lucky, 1977).

\section{2- Identification of Parasites}

The isolated parasites were identified according to (Bray et al., 2005) for trematodes, and (BunkleyWilliams and Williams, 1996; and Vernon, 2006) for cestodes and nematodes, respectively.

\section{II- Antimicrobial susceptibility testing}

Antimicrobial susceptibility profiles of isolates were tested against four antimicrobial agents from different antimicrobial groups of the commonly used in ducks' treatment (Neomycin, sultamethoxazole trimethoprim, chlortetracycline, and florfenicol). According to the standard Kirby-Bauer disc diffusion method (Quinn et al., 1994) and the results were interpreted according to the criteria recommended by (CLSI, 2015).

\section{III- Molecular detection of antibiotic resistance, biofilm and virulence genes}

\section{DNA extraction}

DNA extraction was performed using the QIAamp DNA Mini kit (Qiagen, Germany, GmbH). Briefly, $200 \mu \mathrm{l}$ of sample suspension was incubated with 10 $\mu \mathrm{l}$ of proteinase $\mathrm{K}$ and $200 \mu \mathrm{l}$ of lysis buffer at $56^{\circ} \mathrm{C}$ for $10 \mathrm{~min}$. After incubation, $200 \mu \mathrm{l}$ of $100 \%$ ethanol was added to the lysate. The sample was then washed and centrifuged following the manufacturer's instructions. Nucleic acid was eluted with $100 \mu$ l of elution buffer.

\section{Oligonucleotide Primer}

Primers were supplied from Metabion (Germany) as listed in Table (1).

\section{PCR amplification}

Primers were utilized in a $25-\mu 1$ reaction containing $12.5 \mu 1$ of Emerald Amp Max PCR Master Mix (Takara, Japan), $1 \mu \mathrm{l}$ of each primer of $20 \mathrm{pmol}$ concentration, $4.5 \mu \mathrm{l}$ of water, and $6 \mu \mathrm{l}$ of DNA template. The reaction was performed in an applied biosystem 2720 thermal cycler. 


\section{Stx 1 and stx 2 duplex PCR}

Primers were utilized in a $50 \mu \mathrm{l}$ reaction containing $25 \mu \mathrm{l}$ of Emerald Amp Max PCR Master Mix (Takara, Japan), $1 \mu \mathrm{l}$ of each primer of $20 \mathrm{pmol}$ concentration, $15 \mu \mathrm{l}$ of water, and $6 \mu \mathrm{l}$ of DNA template.

\section{Analysis of the PCR Products}

The products of PCR were separated by electrophoresis on $1.5 \%$ agarose gel (Applichem,
Germany, GmbH) in $1 \mathrm{x}$ TBE buffer at room temperature using gradients of $5 \mathrm{~V} / \mathrm{cm}$. For gel analysis, $20 \mu 1$ of the uniplex PCR products and $40 \mu 1$ of the duplex PCR products were loaded in each gel slot. Gelpilot $100 \mathrm{bp}$ and $100 \mathrm{bp}$ plus DNA ladders (Qiagen, Germany, GmbH) and gene ruler 100 bp ladder (Fermentas, Germany) were used to determine the fragment sizes. The gel was photographed by a gel documentation system (Alpha Innotech, Biometra).

Table 1: Primers' sequences, target genes and amplicon sizes.

\begin{tabular}{|c|c|c|c|c|}
\hline Test Target & $\begin{array}{l}\text { Target } \\
\text { gene }\end{array}$ & $\begin{array}{c}\text { Primers' sequences } \\
\left(5^{\prime}-3^{\prime}\right)\end{array}$ & $\begin{array}{l}\text { Amplified } \\
\text { segment } \\
\text { (bp) }\end{array}$ & References \\
\hline \multirow{2}{*}{$\begin{array}{c}\text { E. coli } \\
\text { Conserved virulence gene }\end{array}$} & \multirow{2}{*}{ phoA } & CGATTCTGGAAATGGCAAAAG & \multirow{2}{*}{720} & \multirow{2}{*}{$\begin{array}{l}\text { Hu et al., } \\
\quad 2011\end{array}$} \\
\hline & & CGTGATCAGCGGTGACTATGAC & & \\
\hline \multirow{3}{*}{$\begin{array}{l}\text { Salmonella spp. } \\
\text { Conserved virulence gene }\end{array}$} & \multirow{3}{*}{$\operatorname{invA}$} & GTGAAATTATCGCCACGTTCGGGC & \multirow{3}{*}{284} & \multirow{3}{*}{$\begin{array}{l}\text { Oliveira } \\
\text { et al., } 2003\end{array}$} \\
\hline & & AA & & \\
\hline & & TCATCGCACCGTCAAAGGAACC & & \\
\hline \multirow{2}{*}{$\begin{array}{l}\text { Pseudomonas } \\
\text { Conserved gene }\end{array}$} & \multirow{2}{*}{$\begin{array}{c}16 S \\
r R N A\end{array}$} & GACGGGTGAGTAATGCCTA & \multirow{2}{*}{618} & \multirow{2}{*}{$\begin{array}{c}\text { Spilker } \\
\text { et al., } 2004\end{array}$} \\
\hline & & CACTGGTGTTCCTTCCTATA & & \\
\hline \multirow{3}{*}{$\begin{array}{l}\text { Salmonella spp } \\
\text { Virulence gene }\end{array}$} & \multirow{3}{*}{ stn } & TTG TGT CGC TAT CAC TGG CAA & \multirow{3}{*}{617} & \multirow{3}{*}{$\begin{array}{l}\text { Murugkar } \\
\text { et al., } 2003\end{array}$} \\
\hline & & $\mathrm{CC}$ & & \\
\hline & & ATT CGT AAC CCG CTC TCG TCC & & \\
\hline \multirow{2}{*}{$\begin{array}{c}\text { E. coli } \\
\text { Virulence gene }\end{array}$} & \multirow{2}{*}{ stx 1} & ACACTGGATGATCTCAGTGG & \multirow{2}{*}{614} & \multirow{4}{*}{$\begin{array}{l}\text { Dipineto } \\
\text { et al., } 2006\end{array}$} \\
\hline & & CTGAATCCCCCTCCATTATG & & \\
\hline E. coli & \multirow{2}{*}{ stx 2} & CCATGACAACGGACAGCAGTT & \multirow{2}{*}{779} & \\
\hline Virulence gene & & CCTGTCAACTGAGCAGCACTTTG & & \\
\hline \multirow{2}{*}{$\begin{array}{l}\text { Pseudomonas } \\
\text { Virulence gene }\end{array}$} & \multirow{2}{*}{$\operatorname{tox} \mathbf{A}$} & GACAACGCCCTCAGCATCACCAGC & \multirow{2}{*}{396} & \multirow{2}{*}{$\begin{array}{c}\text { Matar } \\
\text { et al., } 2002 \\
\end{array}$} \\
\hline & & CGCTGGCCCATTCGCTCCAGCGCT & & \\
\hline \multirow{2}{*}{$\begin{array}{l}\text { Pseudomonas } \\
\text { Virulence gene }\end{array}$} & \multirow{2}{*}{ lasI } & ATGATCGTACAAATTGGTCGGC & \multirow{2}{*}{606} & \multirow{2}{*}{$\begin{array}{l}\text { Bratu et al. } \\
2006\end{array}$} \\
\hline & & GTCATGAAACCGCCAGTCG & & \\
\hline \multirow{2}{*}{$\begin{array}{c}\text { E. coli Salmonella and } \\
\text { pseudomonas } \\
\text { Florophenicol resistance } \\
\text { gene }\end{array}$} & \multirow[b]{2}{*}{ flo R } & TTTGGWCCGCTMTCRGAC & \multirow[b]{2}{*}{494} & \multirow[b]{2}{*}{$\begin{array}{c}\text { Doublet } \\
\text { et al., } 2003\end{array}$} \\
\hline & & SGAGAARAAGACGAAGAAG & & \\
\hline E. coli and Salmonella & $\operatorname{adr} \mathrm{A}$ & ATGTTCCCAAAAATAATGAA & 1113 & Bhowmick \\
\hline Biofilm gene & är & TCATGCCGCCACTTCGGTGC & $111 J$ & et al., 2011 \\
\hline Pseudomonas & $n s / A$ & TCCCTACCTCAGCAGCAAGC & 656 & Ghadaksaz \\
\hline Biofilm gene & PStA & TGTTGTAGCCGTAGCGTTTCTG & 050 & et al., 2015 \\
\hline
\end{tabular}

Conserved genes for species confirmation, phoA: Alkaline phosphastase gene, invA: invasion of the host epithelial cells, 16S rRNA: conserved pseudomonas genus-specific gene. Toxin encoding genes, stn: salmonlla enterotoxin gene, stx1, stx2: E.coli shiga toxins 1 and 2 genes, tox $\mathbf{A}$ gene: pseudomonas exotoxin A gene, lasI gene: quoram sensing transcriptional activator. Antimicrobial resistance genes, floR: Florophenicol resistance gene. Biofilmm formation encoding genes, adrA gene: attenuator of drug resistance of E.coli and salmonella spp, PslA: polysaccharide synthesis locus of pseudomonas spp. 


\section{RESULTS}

\section{I.A. Isolation of bacterial pathogens}

Table 2: Prevalence rate of bacterial isolates.

\begin{tabular}{ccccccc}
\hline \multirow{2}{*}{$\begin{array}{c}\text { Source of } \\
\text { samples }\end{array}$} & \multicolumn{6}{c}{ Prevalence rate of bacterial isolates } \\
\cline { 2 - 7 } & E. coli & \multicolumn{4}{c}{ Salmonella spp } & Pseudomonas spp \\
\cline { 2 - 7 } & Number & Prevalence & Number & Prevalence & Number & Prevalence \\
\hline Duck & $47 / 100$ & $47 \%$ & $25 / 100$ & $25 \%$ & $15 / 100$ & $15 \%$ \\
\hline Fish & $59 / 100$ & $59 \%$ & $9 / 100$ & $9 \%$ & $34 / 100$ & $34 \%$ \\
\hline Total & $106 / 200$ & $53 \%$ & $34 / 200$ & $17 \%$ & $49 / 200$ & $24.5 \%$ \\
\hline
\end{tabular}

One hundred and six out of total two hundred examined samples $(53 \%)$ were positive for E.coli, of which 47/100 (47\%) were isolated from ducks and $59 / 100(59 \%)$ from fish (Tilapia Zillii). Moreover, examination of samples also revealed the isolation of $34 / 200$ (17\%) Salmonella isolates, of which 25/100
$(25 \%)$ isolates were isolated from ducks, 9/100 (9\%) from fish (Tilapia Zillii). The study also revealed the isolation of 49/200 (24.5\%) pseudomonas spp of which 15/100 (15\%) from ducks, and 34/100 (34\%) from fish (Tilapia Zillii), respectively, Table (2).

Table 3: Distribution of bacterial isolates in different samples

\begin{tabular}{|c|c|c|c|c|c|c|}
\hline $\begin{array}{c}\text { Source of } \\
\text { samples }\end{array}$ & \multicolumn{3}{|c|}{ Ducks (100 birds) } & \multicolumn{3}{|c|}{ Fish (100 Tilapia Zillii) } \\
\hline $\begin{array}{c}\text { Type of } \\
\text { infection }\end{array}$ & Bacterial species & $\begin{array}{c}\text { Number } \\
\text { of isolates }\end{array}$ & $\begin{array}{c}\text { Prevalence } \\
\text { rate } \\
\end{array}$ & Bacterial species & $\begin{array}{c}\text { Number } \\
\text { of isolates }\end{array}$ & $\begin{array}{c}\text { Prevalence } \\
\text { rate }\end{array}$ \\
\hline \multirow{3}{*}{$\begin{array}{l}\text { Single } \\
\text { bacterial } \\
\text { infection }\end{array}$} & E.coli & $40 / 100$ & $40 \%$ & E.coli & $30 / 100$ & $30 \%$ \\
\hline & Salmonella spp & $18 / 100$ & $18 \%$ & Salmonella spp. & $4 / 100$ & $4 \%$ \\
\hline & Pseudomonas spp & $15 / 100$ & $15 \%$ & Pseudomonas spp & $10 / 100$ & $10 \%$ \\
\hline \multirow{2}{*}{$\begin{array}{c}\text { Mixed } \\
\text { bacterial } \\
\text { infection }\end{array}$} & \multirow{2}{*}{$\begin{array}{c}\text { E.coli } \\
\text { and Salmonella } \\
\text { spp. }\end{array}$} & \multirow[b]{2}{*}{$7 / 100$} & \multirow[b]{2}{*}{$7 \%$} & $\begin{array}{c}\text { E.coli and } \\
\text { Salmonella spp. }\end{array}$ & $5 / 100$ & $5 \%$ \\
\hline & & & & $\begin{array}{c}\text { E.coli } \\
\text { and pseudomonas } \\
\text { spp }\end{array}$ & $24 / 100$ & $24 \%$ \\
\hline
\end{tabular}

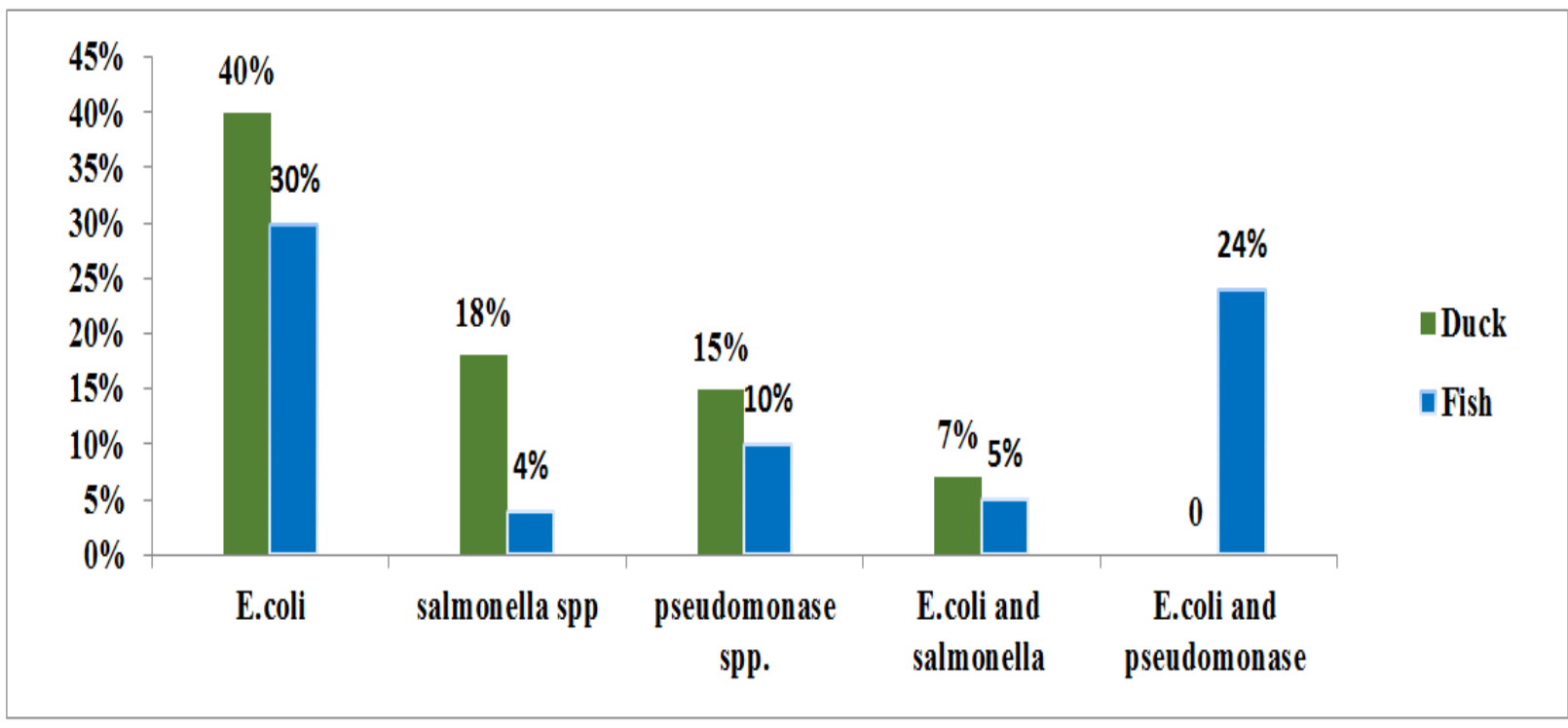

Graph (1): Distribution of bacterial isolates in different samples 
Bacteriological examination of ducks revealed that $7 / 100(7 \%)$ of examined birds were positive for mixed infection by E.coli and salmonella spp. In the same regards, conventional bacteriological examination also revealed that 40/100 (40\%), 18/100 (18\%), and 15/100 (15\%) of examined ducks suffered from single bacterial infection by E.coli, Salmonella spp., and pseudomonase spp, respectively. Bacteriological examination of fish (Tilapia Zillii) samples, revealed that 5/100 (5\%), 24/100 (24\%) of examined fish (Tilapia Zillii) samples were positive for mixed infection by (E.coli and salmonella spp.), and (E.coli and pseudomonase spp), respectively.

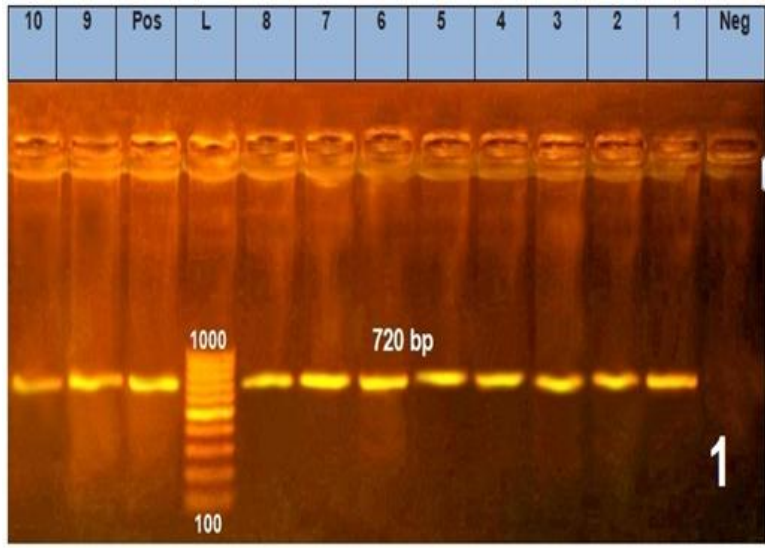

Figure (1): phoA gene for E.coli spp.

Lane L: DNA molecular size marker 100-1000bp

Lane (Pos): Positive control

Lane (Neg): Negative control

Lane 1-10: Positive for phoA gene at $720 \mathrm{bp}$.
Examination also revealed that $30 / 100 \quad(30 \%)$, $4 / 100(4 \%)$ and $10 / 100(10 \%)$ of examined fish (Tilapia Zillii) samples were positive for single bacterial infection by E.coli, Salmonellla spp. and pseudomonase spp., respectively, Graph (1), and Table (3).

\section{Confirmation of Isolates by PCR}

PCR was applied to confirm the results of conventional isolation through targeting the relevant species conserved genes as demonstrated in Figures (1,2 and 3).

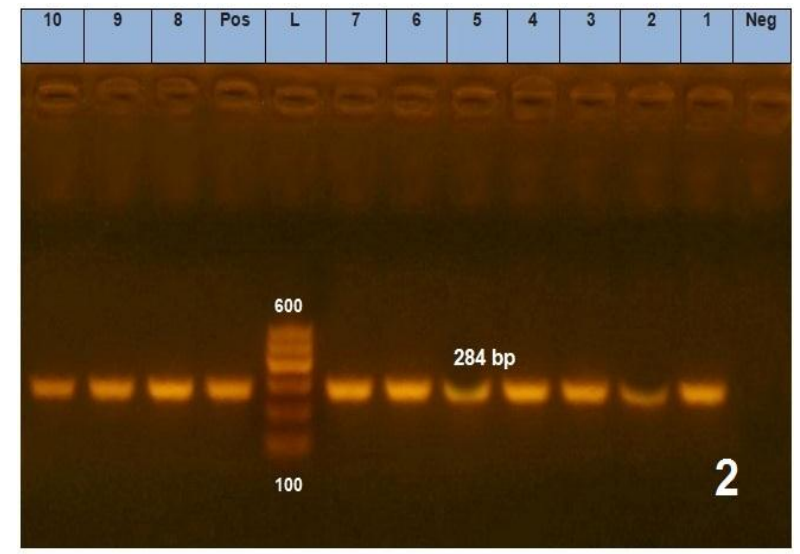

Figure (2): invA gene for salmonella spp Lane L: DNA molecular size marker 100-600bp Lane (Pos): Positive control Lane (Neg): Negative control Lane 1-10: Positive for invA gene at $284 \mathrm{bp}$

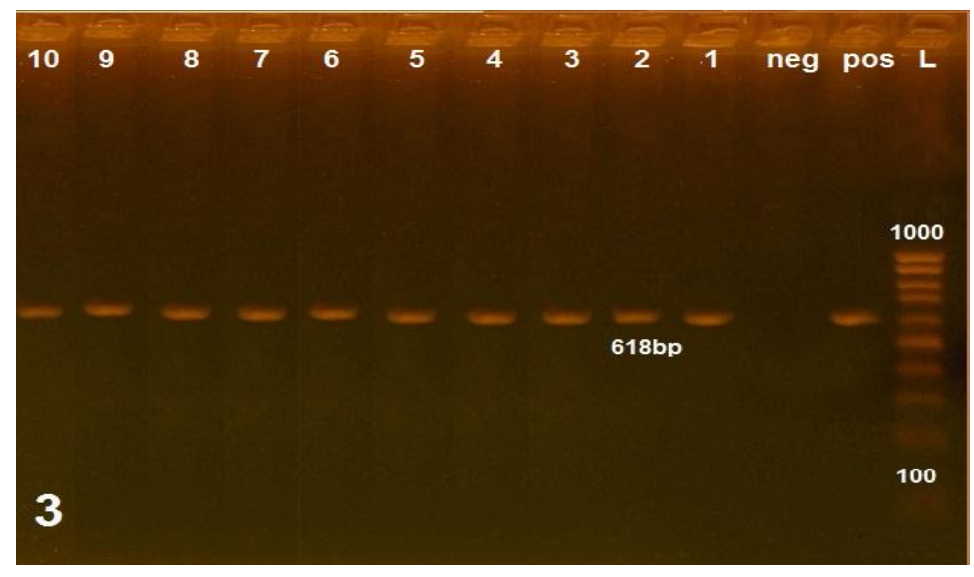

Figure (3): 16S rRNA gene of pseudomonas spp.

Lane L: DNA molecular size marker 100-1000 bp

Lane (Pos): Positive control

Lane (Neg): Negative control

Lane 1-10: Positive for $16 S$ rRNA gene at $618 \mathrm{bp}$ 
Ten E.coli isolates and 10 salmonella isolates isolated from ten cases of mixed bacterial infections (5 ducks, and 5 fish) produced the target specific amplicons for phoA gene, invA gene, the conserved genes for E.coli spp, genus salmonella, respectively. Moreover, a total of 10 pseudomonas isolates with multidrug resistance phenotypes ( 5 isolates from ducks and 5 isolates from fish) were positive for $16 \mathrm{~S} r R N A$ gene the conserved gene for genus pseudomonas., figures $(1,2,3)$.

\section{I.B. Typing of bacterial isolates}

Table 4: Serotyping of $E$. coli isolates.

\begin{tabular}{cccc}
\hline \multirow{2}{*}{ Serotype } & \multicolumn{2}{c}{ No. of isolates } & \multirow{2}{*}{ Total } \\
\cline { 2 - 4 } & Ducks & Fish & $10 / 106$ \\
\hline O146: H21 & $10 / 47$ & $0 / 59$ & $1 / 106$ \\
\hline O124 & $1 / 47$ & $0 / 59$ & $6 / 106$ \\
\hline O155 $:$ H7 & $6 / 47$ & $0 / 59$ & $2 / 106$ \\
\hline O127 & $2 / 47$ & $0 / 59$ & $18 / 106$ \\
\hline O126 : H11 $:$ H21 & $3 / 47$ & $15 / 59$ & $29 / 106$ \\
\hline O17 : H18 & $7 / 47$ & $22 / 59$ & $15 / 106$ \\
\hline Total & $6 / 47$ & $9 / 59$ & $25 / 106$ \\
\hline
\end{tabular}

Serotyping of E.coli isolates revealed their distribution in eight serotypes, from which four serotypes were isolated from ducks and fish (Tilapia Zillii) as follows, O26:H11 (29/106), O17:H18 (25/106), O127 (18/106), and O125: H21 (15/106), respectively, Table (4).

Table 5: Serotyping of salmonella spp. serovars

\begin{tabular}{cccccc}
\hline \multirow{2}{*}{ Serovars } & \multicolumn{2}{c}{ Antigenic structure } & \multicolumn{2}{c}{ Number of isolates } & \multirow{2}{*}{ Total } \\
\cline { 2 - 5 } & $\mathbf{O}$ & $\mathbf{H}$ & Ducks & Fish & \\
\hline Salmonella Molade & 8,20 & $\mathrm{Z} 10: \mathrm{Z6}$ & $4 / 25$ & $0 / 9$ & $2 / 34$ \\
\hline Salmonella Papuana & 6,7 & $\mathrm{r}: \mathrm{e}, \mathrm{n}, \mathrm{Z} 15$ & $2 / 25$ & $0 / 9$ & $4 / 34$ \\
\hline Salmonella Enteritidis & $1,9,12$ & $\mathrm{~g}, \mathrm{~m}:-$ & $3 / 25$ & $1 / 9$ & $5 / 34$ \\
\hline Salmonella Kentucky & 8,20 & $\mathrm{i}: \mathrm{Z} 6$ & $5 / 25$ & $0 / 9$ & $4 / 34$ \\
\hline Salmonella Saintpaul & 4,12 & $\mathrm{i}: \mathrm{Z6}$ & $2 / 25$ & $2 / 9$ & $5 / 34$ \\
\hline Salmonella Anatum & 6,7 & $\mathrm{r}: 1,5$ & $3 / 25$ & $2 / 9$ & $5 / 34$ \\
\hline Salmonella Typhimurium & $1,4,5,12$ & $\mathrm{i}: 1,2$ & $2 / 25$ & $3 / 9$ & $5 / 34$ \\
\hline Salmonella Heidelberg & $1,4,5,12$ & $\mathrm{r}: 1,2$ & $4 / 25$ & $1 / 9$ & $34 / 34$ \\
\hline Total & & & $25 / 25$ & $9 / 9$ & \\
\hline
\end{tabular}

Serotyping of salmonella isolates revealed the detection of 8 serotypes, of which five serotypes were isolated from both ducks and fish (Tilapia Zillii) as follows, Salmonella Enteritidis and Salmonella Saintpaul (4/34) isolates each, Salmonella Anatum, Salmonella Typhimurium and Salmonella Heidelberg (5/34) isolates each, Table (5).

Table 6: Biotyping of pseudomonas spp. Isolates

\begin{tabular}{cccc}
\hline & \multicolumn{2}{c}{ No. of isolates } & \multirow{2}{*}{ Total } \\
\cline { 2 - 3 } & Ducks & Fish & \\
\hline Pseudomonas fluorescens & $9 / 15$ & $25 / 34$ & $34 / 49$ \\
\hline Pseudomonas aeruginosa & $6 / 15$ & $9 / 34$ & $15 / 49$ \\
\hline Total & $15 / 15$ & $34 / 34$ & $49 / 49$ \\
\hline
\end{tabular}

Biotyping of pseudomonus isolates revealed the identification of two biotypes which were isolated from ducks and fish (Tilapia Zillii) as follows, Pseudomonas fluorescens in (34/49) isolates, and pseudomonas aeruginosa in (15/49) isolates, Table (6). 


\section{I.C. Parasitological Examination}

Table 7: Prevalence rate of helminthes parasites in ducks and fish

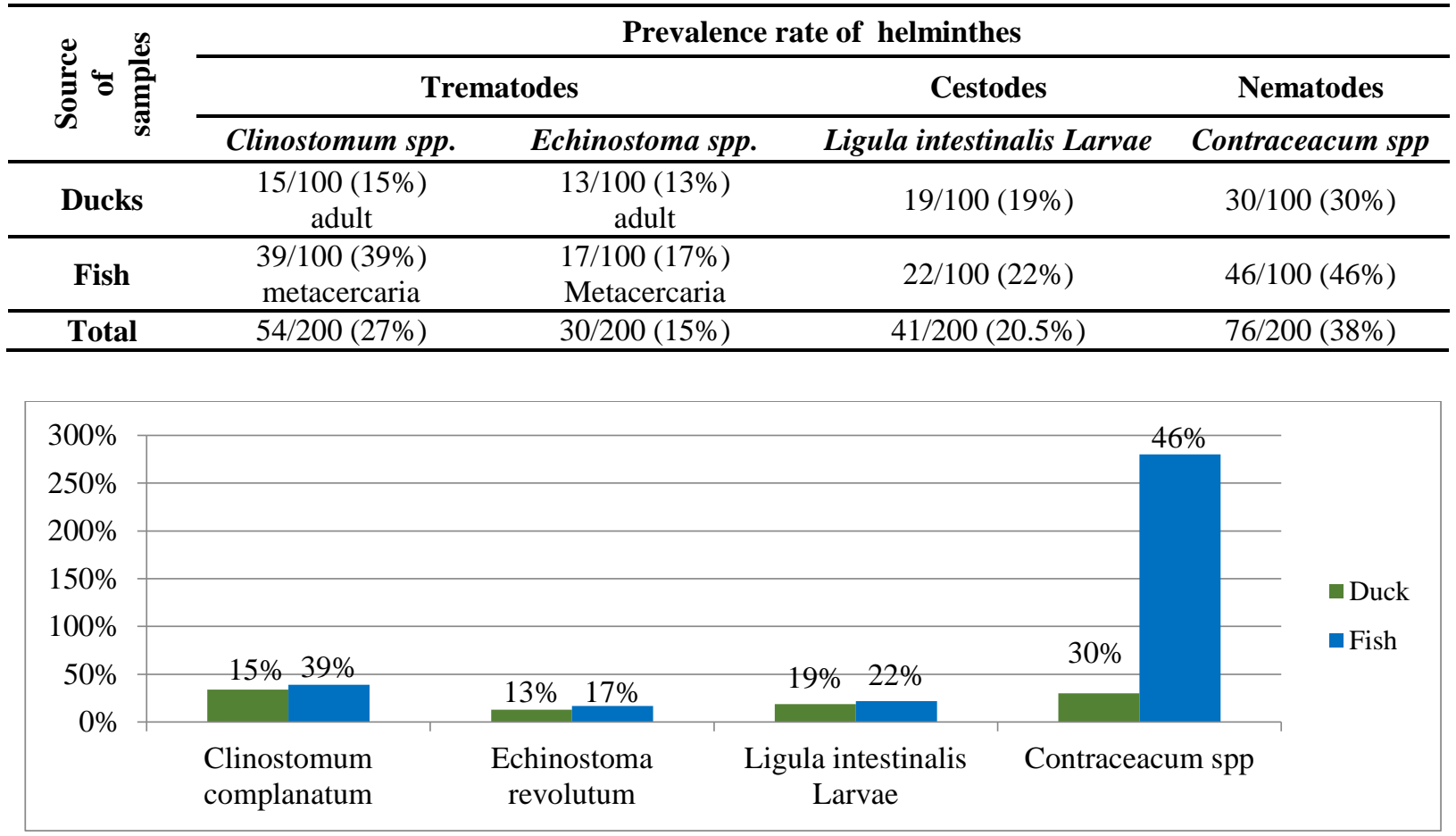

Graph (2): Prevalence rates of helminthes parasites in ducks and fish

In the present study, a total of 100 ducks and 100 Tilapia zillii fish were examined for helminthes infestations. Two species of trematodes were isolated, first of which Echinostoma species with a total prevalence rate of 30/200 (15\%) from total examined 200 ducks and fish, out of which 13/100 (13\%) were isolated from ducks and 17/100 (17\%) were isolated from Tilapia zillii, respectively. Secondly, Clinostomum species was isolated with a total prevalence rate of $54 / 200(27 \%)$ of the total 200 examined ducks and fish, of which 15/100 (15\%) and 39/100 (39\%) were isolated from ducks and Tilapia zillii, respectively. Examination also revealed the isolation of one species of cestodes, Ligula intestinalis larvae with a total prevalence rate of $41 / 200(20.5 \%)$ from the 200 examined ducks and fish, out of which (19/100 (19\%) were isolated from ducks and 22/100 (22\%) were isolated from Tilapia zillii. Examination also revealed the isolation of one species of nematodes, Contraceacum species with a total prevalence rate of $76 / 200(38 \%)$ of examined ducks and fish, out of which $30 / 100(30 \%)$ were isolated from ducks and 46/100 (46\%) were isolated from Tilapia zillii, respectively, graph (2), and table (7).

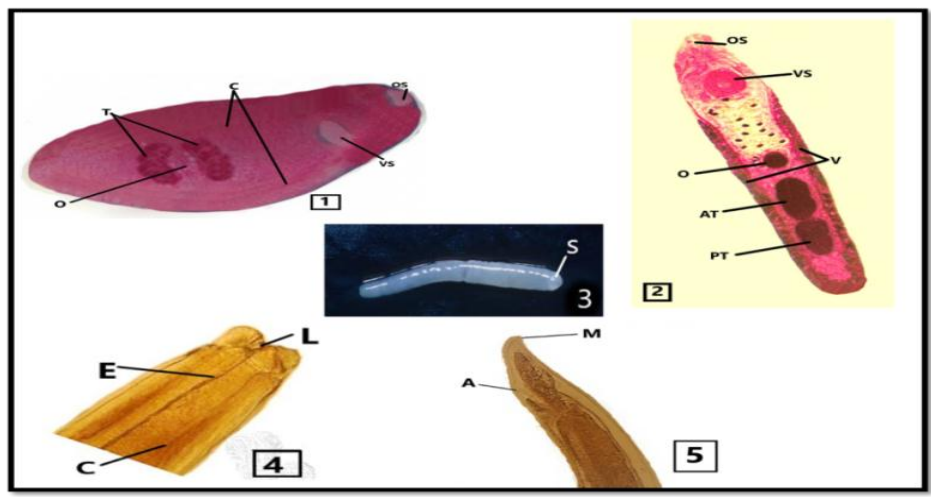

Figure (4), figure (4.1) Clinostomum spp. (OS: Oral Sucker; VS: Ventral Sucker; C: Ceca; T: Testis; O: Ovary), figure (4.2) Echinostoma spp. (OS: Oral Sucker; VS: Ventral Sucker; O: Ovary; V: Vitellaria; AT: Anterior Testis; PT: Posterior testis), figure (4.3) Ligula intestinalis (S: Scolex), figure (4.4) Anterior end of Contraceacum spp. (L: Lips; E: Esophagus; C: Ceca) figure (4.5) Posterior end of Contraceacum spp. (M: Mucron; A: Anus). 
Description and identification of Helminthes Parasites

The helminthic fauna isolated in this study represented the most helminthes species that were commonly found in all habitats and ducks as the main final host encounter the infection by eating snails or fish containing helminthes parasites.

\section{Trematodes}

\subsection{Clinostomum complanatum}

\section{Habitat}

Metacercaria are found on the gills and skin of Tilapia zillii (fish), while adults are found in buccal cavity and esophagus of ducks.

Clinostomum complanatum adult is described as having narrow anterior end, small oral sucker, ceca are bifurcated, extended from ventral sucker to posterior end, triangular median testis, oval ovary, figure (4.1).

\subsection{Echinostoma revolutum}

\section{Habitat}

Metacercaria are found in the intestine of Tilapia zilli (fish) and the adult are found in the intestine of ducks. The adults were found with well-developed head collar, oral sucker sub terminal, sub spherical. Ventral sucker is sub spherical, with deep cavity, located fairly close to anterior extremity of the short esophagus; intestinal bifurcation in second half of fore body; caeca blind, narrow, reach close to posterior extremity of body. Testis are two, tandem, separated, located in third quarter of body. Ovary is sub-globular. Eggs are not very numerous, small.
Vitellarium follicular, forming 2 lateral fields of small follicles overlapping caeca, figure (4.2).

\section{Cestodes}

\subsection{Ligula intestinalis Larvae}

\section{Habitat}

Ligula intestinalis are found in the body cavity of Tilapia zillii (fish) and the adults are found in the intestine of ducks.

The body of these plerocercoids was elongated, solid, whitish and flat, measured $1-14 \mathrm{~cm}$ in length and $0.3-0.85 \mathrm{~cm}$ in width. The external segmentation of strobila was absent. Two bothridial depressions were hardly visible on the anterior end representing of scolex, figure (4.3).

\section{Nematodes \\ 3.1. Contraceacum species Larvae}

\section{Habitat}

Contraceacum spp larvae were found in the intestine of Tilapia zilli (fish) and ducks.

The body is whitish and its length is $2-6 \mathrm{~mm}$, relatively thick with maximum width of 0.19-0.23 $\mathrm{mm}$ at the middle of the body. The isolated nematodes have 3 lips around the mouth opening, without ridges. Intestinal cecum is well developed with one esophageal appendix. Esophagus ends in short. Intestine is filling the remainder of body. Tail sharply pointed, with spine, figure (4.4 and 4.5).

II- Studying the phenotypic antimicrobial resistance profiles of bacterial isolates

Table 8: Phenotypic resistance profiles

\begin{tabular}{|c|c|c|c|c|c|c|c|}
\hline \multirow{2}{*}{$\begin{array}{c}\text { Chemotherapeutic } \\
\text { Group }\end{array}$} & \multirow{2}{*}{$\begin{array}{c}\text { Bacterial isolates } \\
\begin{array}{c}\text { Chemotherapeutic } \\
\text { agents }\end{array}\end{array}$} & \multicolumn{2}{|c|}{ E. coli isolates } & \multicolumn{2}{|c|}{ Salmonella isolates } & \multicolumn{2}{|c|}{ Pseudomonas isolates } \\
\hline & & $\begin{array}{l}\text { No. of } \\
\text { Resistant } \\
\text { isolates }\end{array}$ & $\begin{array}{l}\text { Resistance } \\
\text { rate }\end{array}$ & $\begin{array}{l}\text { No. of } \\
\text { Resistant } \\
\text { isolates }\end{array}$ & $\begin{array}{l}\text { Resistance } \\
\text { rate }\end{array}$ & $\begin{array}{c}\text { No. of } \\
\text { Resistant } \\
\text { isolates }\end{array}$ & $\begin{array}{c}\text { Resistance } \\
\text { rate }\end{array}$ \\
\hline Aminoglycosides & Neomycin(N), 30ug & $103 / 106$ & $97.1 \%$ & $34 / 34$ & $100 \%$ & $49 / 49$ & $100 \%$ \\
\hline Diaminopyrimidine & $\begin{array}{c}\text { Sulfamethoxazole- } \\
\text { trimethoprim (SXT), } \\
\text { 25ug }\end{array}$ & $97 / 106$ & $91.5 \%$ & $31 / 34$ & $91.2 \%$ & $45 / 49$ & $91.8 \%$ \\
\hline Tetracycline & $\begin{array}{l}\text { Chlortetracycline } \\
\text { (CL), 15ug }\end{array}$ & $100 / 106$ & $94.3 \%$ & $30 / 34$ & $88.2 \%$ & $46 / 49$ & $93.9 \%$ \\
\hline Quinolones & $\begin{array}{l}\text { Florfenicol (FL), } \\
\text { 30ug }\end{array}$ & $90 / 106$ & $84.3 \%$ & $29 / 34$ & $85.3 \%$ & $44 / 49$ & $89.8 \%$ \\
\hline
\end{tabular}

Resistance rates were calculated with regards to the total number of isolated species, the results revealed that $97 / 106(91.5 \%)$ of E. coli, 30/34 (88.2\%) of Salmonella spp. and 45/49 (91.8\%) pseudomonas spp. demonstrated multidrug resistance phenotypes, table (8). 


\section{III-Investigation of genotypic virulence attributes of isolates by PCR}

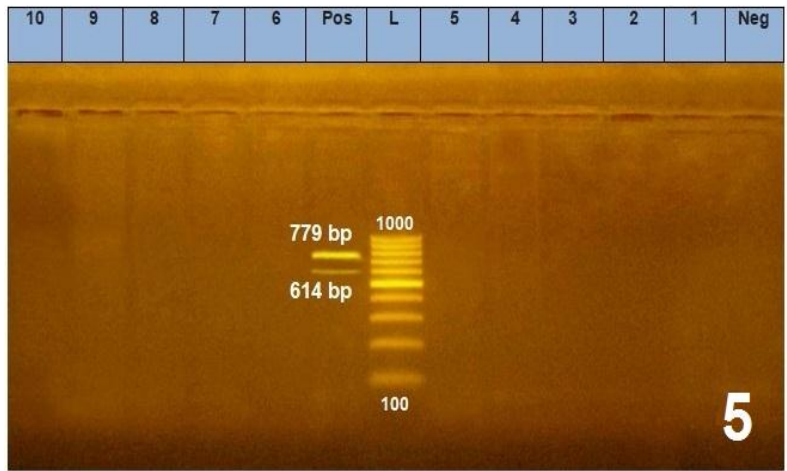

Figure (5): stx1, stx 2 gene for E.coli spp.

Lane L: DNA molecular size marker 100-1000 bp

Lane (Pos): Positive control

Lane (Neg): Negative control

Lane 1-10: Negative for $s t x 1,2$ genes at $614,779 \mathrm{bp}$, respectively

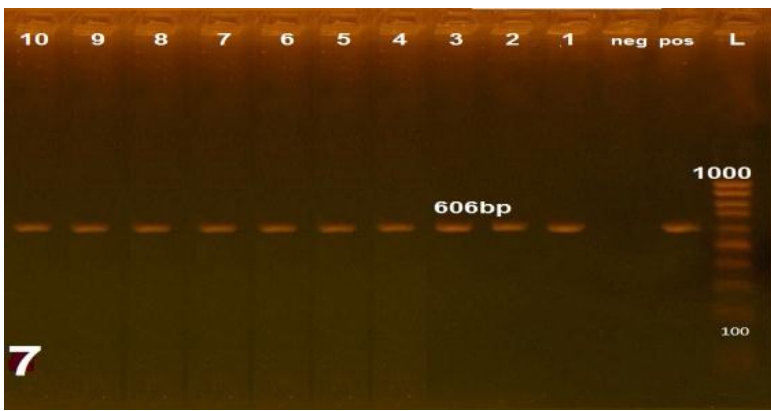

Figure (7): lasI gene for pseudomonas spp

Lane L: DNA molecular size marker 100-1000 bp

Lane (Pos): Positive control

Lane (Neg): Negative control

Lane 1-10: positive for lasI gene at $606 \mathrm{bp}$

E.coli and Salmonella spp. isolated from ten cases of mixed bacterial infections ( 5 in ducks, and 5 in fish) and that demonstrated multidrug resistance phenotypes were tested for genotypic virulence attributes. In this regards, PCR failed to detect neither st $x$, nor st 2 virulence genes of E.coli, figure (5). On the other hand, PCR confirmed the detection of stn

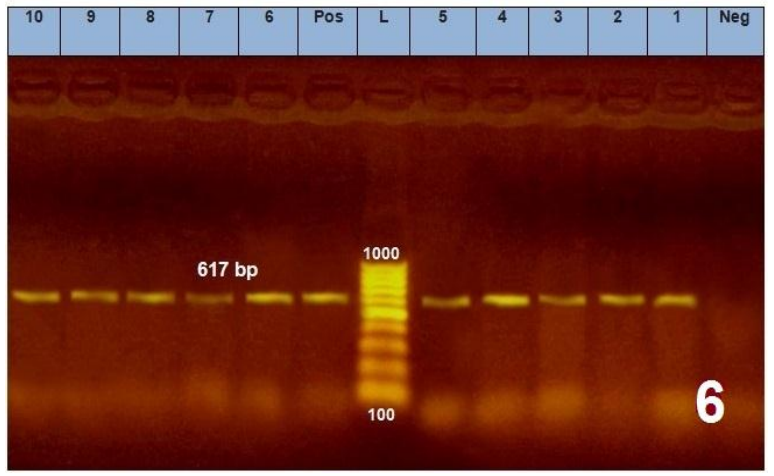

Figure (6): stn gene for salmonella spp.

Lane L: DNA molecular size marker 100-1000 bp

Lane (Pos): Positive control

Lane (Neg): Negative control

Lane 1-10: positive for stn gene at $617 \mathrm{bp}$

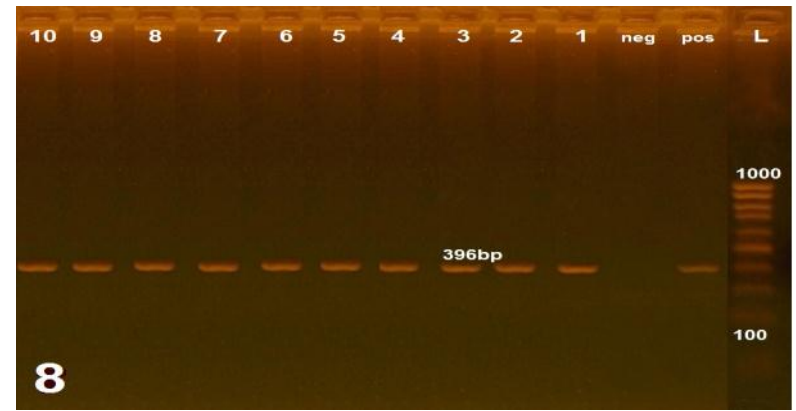

Figure (8): toxA gene for pseudomonas spp

Lane L: DNA molecular size marker 100-1000 bp

Lane (Pos): Positive control

Lane (Neg): Negative control

Lane 1-10: positive for toxA gene at $396 \mathrm{bp}$

gene of Salmonella spp. in 10/10 (100\%) of tested isolates, figure (6).

The presence of lasI and toxA virulence genes was by confirmed in PCR in 10 randomly selected pseudomonas spp isolates that demonstrated multidrug resistance phenotypes, figure $(7,8)$.

\section{IV-Investigation of genotypic resistance attributes of isolates by PCR}

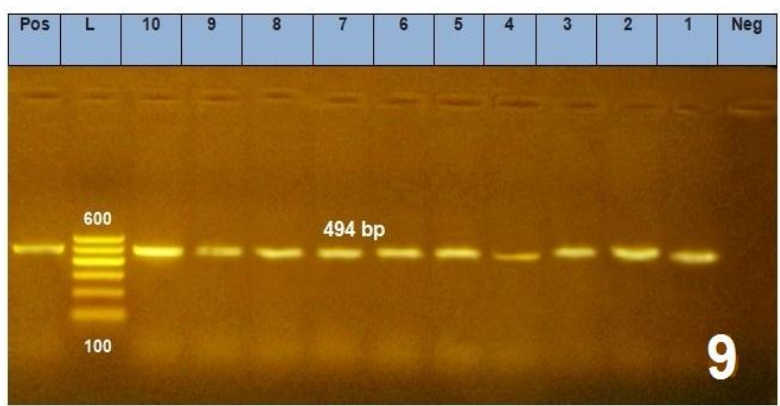

Figure (9): floR resistance gene for E.coli spp Lane L: DNA molecular size marker 100-600 bp Lane (Pos): Positive control Lane (Neg): Negative control

Lane 1-10: positive for floR gene at $494 \mathrm{bp}$

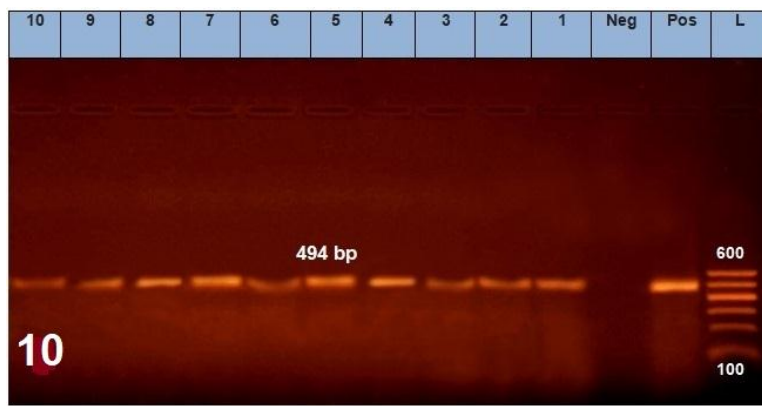

Figure (10): floR gene for salmonella spp Lane L: DNA molecular size marker 100-600 bp Lane (Pos): Positive control Lane (Neg): Negative control Lane 1-10: positive for floR gene at $494 \mathrm{bp}$ 


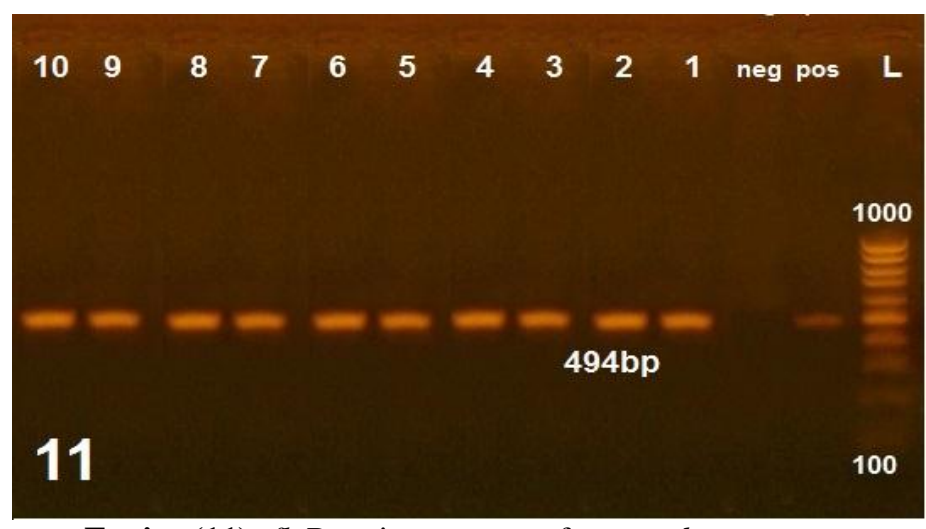

Fguire (11): floR resistance gene for pseudomonas spp Lane L: DNA molecular size marker 100-1000 bp

Lane (Pos): Positive control

Lane (Neg): Negative control

Lanes 1-10: positive for floR gene at $494 \mathrm{bp}$

Florophenicol resistance genotypic attributes was tested by PCR for the presence of floR gene and was confirmed in 10/10 (100\%) of each of the tested E.coli, salmonella spp. and pseudomonas spp isolates, figure (9.10 and 11).

\section{V-Investigation of genotypic biofilm attributes of isolates by PCR}

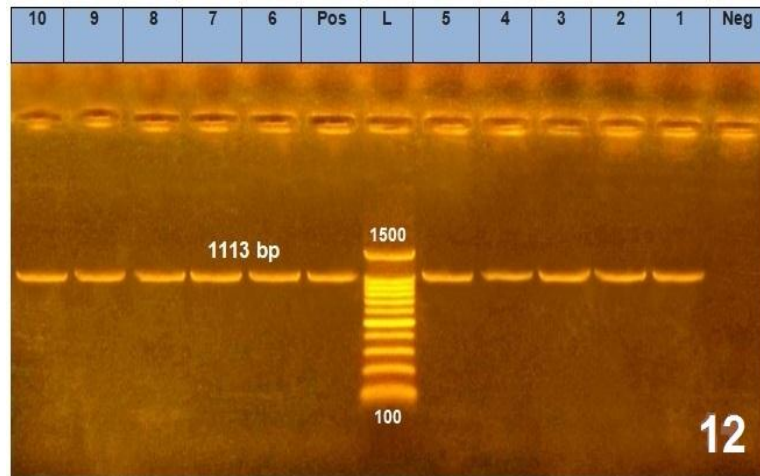

Figure (12): $a d r$ A biofilm gene for E.coli spp Lane L: DNA molecular size marker 100-1500 bp Lane (Pos): Positive control Lane (Neg): Negative control Lane 1-10: positive for $a d r \mathrm{~A}$ gene at $1113 \mathrm{bp}$

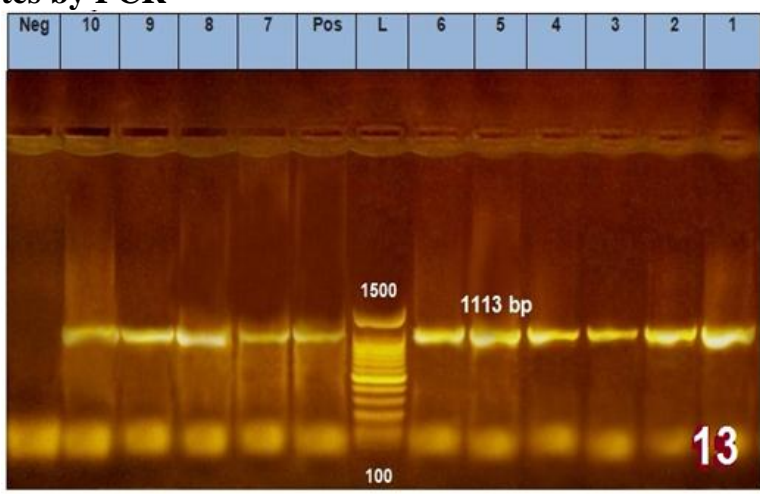

Figure (13): adrA biofilm gene for salmonella spp Lane L: DNA molecular size marker 100-1500bp Lane (Pos): Positive control Lane (Neg): Negative control Lane 1-10: positive for $a d r \mathrm{~A}$ gene at $1113 \mathrm{bp}$

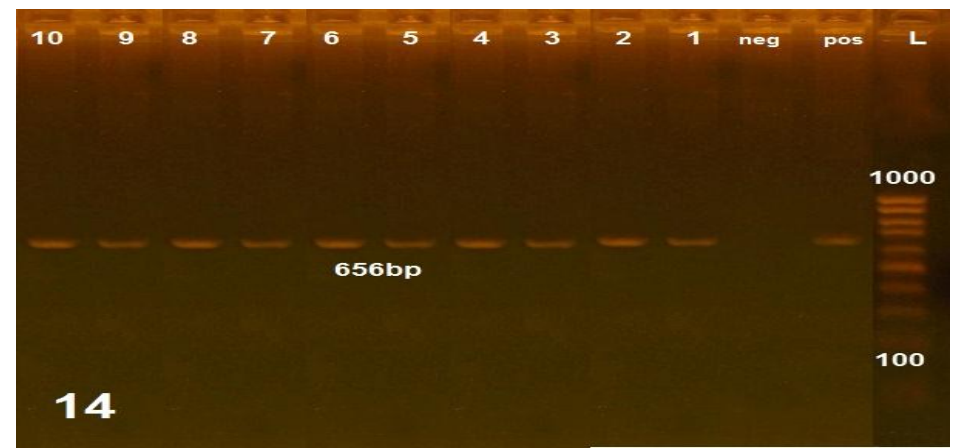

Figure (14): pslA biofilm gene for pseudomonas spp

Lane L: DNA molecular size marker 100-1000 bp.

Lane (Pos): Positive control

Lane (Neg): Negative control

Lane 1-10: positive for $p s l \mathrm{~A}$ gene at $656 \mathrm{bp}$ 
Genetic attributes for biofilm formation were tested by PCR for the presence of $a d r \mathrm{~A}$ gene and were confirmed in 10/10 (100\%) of the tested E.coli and $10 / 10(100 \%)$ of the tested salmonella isolates, figure $(12,13)$. PCR also confirmed the detection of pslA gene for in 10/10 (100\%) of the tested pseudomonas spp isolates, figure (14).

Table 9: Phenotypic, and genotypic resistance and biofilm profiles of E. coli isolates from cases of mixed infection with parasites.

\begin{tabular}{|c|c|c|c|c|c|c|c|c|c|}
\hline \multirow{2}{*}{ No } & \multirow{2}{*}{ Source } & \multirow{2}{*}{ Serotype } & \multirow{2}{*}{ Helminthes } & \multirow{2}{*}{$\begin{array}{c}\text { Antimicrobial } \\
\text { resistance } \\
\text { profile }\end{array}$} & \multirow{2}{*}{$\begin{array}{c}\text { Confirmatory } \\
\text { gene } \\
\text { (phoA) }\end{array}$} & \multicolumn{2}{|c|}{$\begin{array}{l}\text { Virulence } \\
\text { genes }\end{array}$} & \multirow{2}{*}{$\begin{array}{l}\text { Antibiotic } \\
\text { resistance } \\
\text { genes } \\
(f l o \mathrm{R})\end{array}$} & \multirow{2}{*}{$\begin{array}{c}\text { Biofilm } \\
\text { genes } \\
(\text { adrA })\end{array}$} \\
\hline & & & & & & Stx 1 & Stx 2 & & \\
\hline 1 & $\mathrm{D}^{*}$, Mixed & $\begin{array}{c}\text { O146 : } \\
\text { H21 }\end{array}$ & $\begin{array}{c}\text { Clinostomum spp., } \\
\text { Ligula intestinalis } \\
\text { Larvae }\end{array}$ & $\begin{array}{l}\mathrm{N}^{1}, \mathrm{SXT}^{2}, \\
\mathrm{CL}^{3}, \mathrm{FL}^{4}\end{array}$ & + & - & - & + & + \\
\hline 2 & $\mathrm{D}^{*}$, Mixed & 0124 & $\begin{array}{l}\text { Echinostoma spp., } \\
\text { Contraceacum spp. }\end{array}$ & $\begin{array}{l}\mathrm{N}^{1}, \mathrm{SXT}^{2}, \\
\mathrm{CL}^{3}, \mathrm{FL}^{4}\end{array}$ & + & - & - & + & + \\
\hline 3 & $D^{*}$, Mixed & $\mathbf{O 5 5}: \mathbf{H 7}$ & $\begin{array}{l}\text { Clinostomum spp.+ } \\
\text { Contraceacum spp }\end{array}$ & $\begin{array}{l}\mathrm{N}^{1}, \mathrm{SXT}^{2}, \\
\mathrm{CL}^{3}, \mathrm{FL}^{4}\end{array}$ & + & - & - & + & + \\
\hline 4 & $\mathrm{D}^{*}$, Mixed & 0158 & $\begin{array}{c}\text { Clinostomum spp., } \\
\text { Ligula intestinalis } \\
\text { Larvae }\end{array}$ & $\begin{array}{l}\mathrm{N}^{1}, \mathrm{SXT}^{2}, \\
\mathrm{CL}^{3}, \mathrm{FL}^{4}\end{array}$ & + & - & - & + & + \\
\hline 5 & $\mathrm{D}^{*}$, Mixed & 0127 & $\begin{array}{l}\text { Echinostoma spp., } \\
\text { Contraceacum spp. }\end{array}$ & $\begin{array}{l}\mathrm{N}^{1}, \mathrm{SXT}^{2}, \\
\mathrm{CL}^{3}, \mathrm{FL}^{4}\end{array}$ & + & - & - & + & + \\
\hline 6 & $\begin{array}{c}\mathrm{F}^{* *} \\
\text { Mixed }\end{array}$ & $\begin{array}{l}\text { O26 : } \\
\text { H11 }\end{array}$ & $\begin{array}{l}\text { Clinostomum spp., } \\
\text { Contraceacum spp }\end{array}$ & $\begin{array}{l}\mathrm{N}^{1}, \mathrm{SXT}^{2}, \\
\mathrm{CL}^{3}, \mathrm{FL}^{4}\end{array}$ & + & - & - & + & + \\
\hline 7 & $\begin{array}{c}F^{* *} \\
\text { Mixed }\end{array}$ & $\begin{array}{c}\text { O125 : } \\
\text { H21 }\end{array}$ & $\begin{array}{c}\text { Clinostomum spp., } \\
\text { Ligula intestinalis } \\
\text { Larvae }\end{array}$ & $\begin{array}{l}\mathrm{N}^{1}, \mathrm{SXT}^{2}, \\
\mathrm{CL}^{3}, \mathrm{FL}^{4}\end{array}$ & + & - & - & + & + \\
\hline 8 & $\begin{array}{l}\mathrm{F}^{* *} \\
\text { Mixed }\end{array}$ & $\begin{array}{l}\text { O17 : } \\
\text { H18 }\end{array}$ & $\begin{array}{l}\text { Echinostoma spp., } \\
\text { Contraceacum spp }\end{array}$ & $\begin{array}{l}\mathrm{N}^{1}, \mathrm{SXT}^{2}, \\
\mathrm{CL}^{3}, \mathrm{FL}^{4}\end{array}$ & + & - & - & + & + \\
\hline 9 & $\begin{array}{c}\mathrm{F}^{* *} \\
\text { Mixed }\end{array}$ & $\begin{array}{c}\text { O125 : } \\
\text { H21 }\end{array}$ & $\begin{array}{l}\text { Clinostomum spp., } \\
\text { Contraceacum spp }\end{array}$ & $\begin{array}{l}\mathrm{N}^{1}, \mathrm{SXT}^{2}, \\
\mathrm{CL}^{3}, \mathrm{FL}^{4}\end{array}$ & + & - & - & + & + \\
\hline 10 & $\begin{array}{c}\mathrm{F}^{* *} \\
\text { Mixed }\end{array}$ & $\begin{array}{l}\text { O17 : } \\
\text { H18 }\end{array}$ & $\begin{array}{c}\text { Clinostomum spp., } \\
\text { Ligula intestinalis } \\
\text { Larvae }\end{array}$ & $\begin{array}{l}\mathrm{N}^{1}, \mathrm{SXT}^{2}, \\
\mathrm{CL}^{3}, \mathrm{FL}^{4}\end{array}$ & + & - & - & + & + \\
\hline
\end{tabular}

$\mathrm{D}^{*}$ : Ducks, $\mathrm{F}^{* *}$ : Fish, $\mathrm{N}^{1}$ : Neomycin, $\mathrm{SXT}^{2}$ : Sulfamethoxazole-trimethoprim, $\mathrm{CL}^{3}$ : Chlortetracycline, $\mathrm{FL}^{4}$ : Florophenicol 
Table 10: Phenotypic, genotypic resistance and biofilm profiles of salmonella isolates from cases of mixed infection with parasites:

\begin{tabular}{|c|c|c|c|c|c|c|c|c|}
\hline No. & Source & Serotype & Helminths & $\begin{array}{c}\text { Antimicrobial } \\
\text { resistance } \\
\text { profile }\end{array}$ & $\begin{array}{c}\text { Confirmatory } \\
\text { gene } \\
(\text { invA })\end{array}$ & $\begin{array}{l}\text { Virulence } \\
\text { genes } \\
(s t n)\end{array}$ & $\begin{array}{c}\text { Antibiotic } \\
\text { resistance } \\
\text { genes } \\
(\text { floR }) \\
\end{array}$ & $\begin{array}{l}\text { Biofilm } \\
\text { genes } \\
(\text { adrA })\end{array}$ \\
\hline 1 & $\begin{array}{c}\mathrm{D}^{*} \\
\text { Mixed }\end{array}$ & S. Molade & $\begin{array}{c}\text { Clinostomum spp., } \\
\text { Ligula intestinalis } \\
\text { Larvae }\end{array}$ & $\begin{array}{l}\mathrm{N}^{1}, \mathrm{SXT}^{2} \\
\mathrm{CL}^{3}, \mathrm{FL}^{4}\end{array}$ & + & + & + & + \\
\hline 2 & $\begin{array}{c}\mathrm{D}^{*} \\
\text { Mixed }\end{array}$ & S. Papuana & $\begin{array}{l}\text { Clinostomum spp., } \\
\text { Contraceacum spp. }\end{array}$ & $\begin{array}{l}\mathrm{N}^{1}, \mathrm{SXT}^{2} \\
\mathrm{CL}^{3}, \mathrm{FL}^{4} \\
\end{array}$ & + & + & + & + \\
\hline 3 & $\begin{array}{c}\mathrm{D}^{*} \\
\text { Mixed }\end{array}$ & S. Enteritidis & $\begin{array}{c}\text { Clinostomum spp., } \\
\text { Ligula intestinalis } \\
\text { Larvae }\end{array}$ & $\begin{array}{l}\mathrm{N}^{1}, \mathrm{SXT}^{2} \\
\mathrm{CL}^{3}, \mathrm{FL}^{4}\end{array}$ & + & + & + & + \\
\hline 4 & $\begin{array}{c}\mathrm{D}^{*} \\
\text { Mixed }\end{array}$ & S. Kentucky & $\begin{array}{l}\text { Echinostoma spp., } \\
\text { Contraceacum spp. }\end{array}$ & $\begin{array}{l}\mathrm{N}^{1}, \mathrm{SXT}^{2}, \\
\mathrm{CL}^{3}, \mathrm{FL}^{4}\end{array}$ & + & + & + & + \\
\hline 5 & $\begin{array}{c}\mathrm{D}^{*}, \\
\text { Mixed }\end{array}$ & S.saintpaul & $\begin{array}{l}\text { Clinostomum spp., } \\
\text { Contraceacum spp. }\end{array}$ & $\begin{array}{l}\mathrm{N}^{1}, \mathrm{SXT}^{2}, \\
\mathrm{CL}^{3}, \mathrm{FL}^{4}\end{array}$ & + & + & + & + \\
\hline 6 & $\begin{array}{l}\mathrm{F}^{* *} \\
\text { Mixed }\end{array}$ & S. Anatum & $\begin{array}{c}\text { Clinostomum } \\
\text { spp.,Contraceacum } \\
\text { spp. }\end{array}$ & $\begin{array}{l}\mathrm{N}^{1}, \mathrm{SXT}^{2} \\
\mathrm{CL}^{3}, \mathrm{FL}^{4}\end{array}$ & + & + & + & + \\
\hline 7 & $\begin{array}{l}\mathrm{F}^{* *} \\
\text { Mixed }\end{array}$ & $\begin{array}{c}\text { S. } \\
\text { Typhimurium }\end{array}$ & $\begin{array}{c}\text { Clinostomum spp., } \\
\text { Ligula intestinalis } \\
\text { Larvae }\end{array}$ & $\begin{array}{l}\mathrm{N}^{1}, \mathrm{SXT}^{2} \\
\mathrm{CL}^{3}, \mathrm{FL}^{4}\end{array}$ & + & + & + & + \\
\hline 8 & $\begin{array}{c}\mathrm{F}^{* *} \\
\text { Mixed }\end{array}$ & $\begin{array}{c}\text { S. } \\
\text { Heidelberg }\end{array}$ & $\begin{array}{l}\text { Echinostoma spp., } \\
\text { Contraceacum spp. }\end{array}$ & $\begin{array}{l}\mathrm{N}^{1}, \mathrm{SXT}^{2} \\
\mathrm{CL}^{3}, \mathrm{FL}^{4}\end{array}$ & + & + & + & + \\
\hline 9 & $\begin{array}{c}\mathrm{F}^{\text {*** }} \\
\text { Mixed }\end{array}$ & S. Typhimuriun & $\begin{array}{l}\text { Clinostomum spp., } \\
\text { Contraceacum spp. }\end{array}$ & $\begin{array}{l}\mathrm{N}^{1}, \mathrm{SXT}^{2}, \\
\mathrm{CL}^{3}, \mathrm{FL}^{4}\end{array}$ & + & + & + & + \\
\hline 10 & $\begin{array}{l}\mathrm{F}^{* *} \\
\text { Mixed }\end{array}$ & S. Heidelberg & $\begin{array}{c}\text { Clinostomum spp., } \\
\text { Ligula intestinalis } \\
\text { Larvae }\end{array}$ & $\begin{array}{l}\mathrm{N}^{1}, \mathrm{SXT}^{2} \\
\mathrm{CL}^{3}, \mathrm{FL}^{4}\end{array}$ & + & + & + & + \\
\hline
\end{tabular}

$\mathrm{D}^{*}$ : Ducks, $\mathrm{F}^{* *}$ : Fish, $\mathrm{N}^{1}$ : Neomycin, $\mathrm{SXT}^{2}$ : Sulfamethoxazole-trimethoprim, $\mathrm{CL}^{3}$ : Chlortetracycline, $\mathrm{FL}^{4}$ : Florophenicol

Table 11: Phenotypic, genotypic resistance and biofilm profiles of pseudomonas spp. isolates from cases of mixed infection with parasites.

\begin{tabular}{|c|c|c|c|c|c|c|c|c|c|}
\hline \multirow[t]{2}{*}{ No } & \multirow[t]{2}{*}{ Source } & \multirow[t]{2}{*}{ Serotype } & \multirow{2}{*}{ Helminths } & \multirow{2}{*}{$\begin{array}{c}\text { Antimicrobial } \\
\text { resistance } \\
\text { profile }\end{array}$} & \multirow{2}{*}{$\begin{array}{c}\text { Confirmatory } \\
\text { gene } \\
(16 S r R N A)\end{array}$} & \multicolumn{2}{|c|}{$\begin{array}{c}\text { Virulence } \\
\text { genes } \\
(\text { stn })\end{array}$} & \multirow{2}{*}{$\begin{array}{l}\text { Antibiotic } \\
\text { resistance } \\
\text { genes } \\
(\text { flo } \mathbf{R})\end{array}$} & \multirow{2}{*}{$\begin{array}{r}\text { Biofilm } \\
\text { genes } \\
(p s l A)\end{array}$} \\
\hline & & & & & & lasI & $\operatorname{tox} A$ & & \\
\hline 1 & $\mathrm{D}^{*}$, single & P.fluorescens & $\begin{array}{l}\text { Echinostoma spp.+ } \\
\text { Contraceacum spp. }\end{array}$ & $\begin{array}{l}\mathrm{N}^{1}, \mathrm{SXT}^{2}, \\
\mathrm{CL}^{3}, \mathrm{FL}^{4}\end{array}$ & + & + & + & + & + \\
\hline 2 & $\mathrm{D}^{*}$, single & P.fluorescens & $\begin{array}{c}\text { Clinostomum spp.+ } \\
\text { Ligula intestinalis } \\
\text { Larvae }\end{array}$ & $\begin{array}{l}\mathrm{N}^{1}, \mathrm{SXT}^{2}, \\
\mathrm{CL}^{3}, \mathrm{FL}^{4}\end{array}$ & + & + & + & + & + \\
\hline 3 & $\mathrm{D}^{*}$, single & P.fluorescens & $\begin{array}{l}\text { Echinostoma spp.+ } \\
\text { Contraceacum spp. }\end{array}$ & $\begin{array}{l}\mathrm{N}^{1}, \mathrm{SXT}^{2}, \\
\mathrm{CL}^{3}, \mathrm{FL}^{4}\end{array}$ & + & + & + & + & + \\
\hline 4 & $\mathrm{D}^{*}$, single & P.aeruginosa & $\begin{array}{l}\text { Clinostomum spp.+ } \\
\text { Contraceacum spp. }\end{array}$ & $\begin{array}{l}\mathrm{N}^{1}, \mathrm{SXT}^{2}, \\
\mathrm{CL}^{3}, \mathrm{FL}^{4}\end{array}$ & + & + & + & + & + \\
\hline 5 & $\mathrm{D}^{*}$, single & P.aeruginosa & $\begin{array}{l}\text { Clinostomum spp.+ } \\
\text { Contraceacum spp. }\end{array}$ & $\begin{array}{l}\mathrm{N}^{1}, \mathrm{SXT}^{2} \\
\mathrm{CL}^{3}, \mathrm{FL}^{4}\end{array}$ & + & + & + & + & + \\
\hline 6 & $\mathrm{~F}^{* * *}$, single & P.fluorescens & $\begin{array}{c}\text { Clinostomum spp.+ } \\
\text { Ligula intestinalis } \\
\text { Larvae }\end{array}$ & $\begin{array}{c}\mathrm{N}^{1}, \mathrm{SXT}^{2}, \\
\mathrm{CL}^{3}, \mathrm{FL}^{4}\end{array}$ & + & + & + & + & + \\
\hline 7 & $\mathrm{~F}^{* *}$,single & P.fluorescens & $\begin{array}{l}\text { Echinostoma spp.+ } \\
\text { Contraceacum spp. }\end{array}$ & $\begin{array}{l}\mathrm{N}^{1}, \mathrm{SXT}^{2}, \\
\mathrm{CL}^{3}, \mathrm{FL}^{4}\end{array}$ & + & + & + & + & + \\
\hline 8 & $\mathrm{~F}^{* *}$, mixed & P.fluorescens & $\begin{array}{l}\text { Clinostomum spp.+ } \\
\text { Contraceacum spp. }\end{array}$ & $\begin{array}{l}\mathrm{N}^{1}, \mathrm{SXT}^{2} \\
\mathrm{CL}^{3}, \mathrm{FL}^{4}\end{array}$ & + & + & + & + & + \\
\hline 9 & $\mathrm{~F}^{* * *}$,mixed & P.aeruginosa & $\begin{array}{c}\text { Clinostomum spp.+ } \\
\text { Ligula intestinalis } \\
\text { Larvae }\end{array}$ & $\begin{array}{l}\mathrm{N}^{1}, \mathrm{SXT}^{2}, \\
\mathrm{CL}^{3}, \mathrm{FL}^{4}\end{array}$ & + & + & + & + & + \\
\hline 10 & $\mathrm{~F}^{* * *}$,mixed & P.aeruginosa & $\begin{array}{c}\text { Clinostomum spp.+ } \\
\text { Ligula intestinalis } \\
\text { Larvae }\end{array}$ & $\begin{array}{l}\mathrm{N}^{1}, \mathrm{SXT}^{2}, \\
\mathrm{CL}^{3}, \mathrm{FL}^{4}\end{array}$ & + & + & + & + & + \\
\hline
\end{tabular}

$\mathrm{D}^{*}$ : Ducks, $\mathrm{F}^{* *}$ : Fish, $\mathrm{N}^{1}$ : Neomycin, $\mathrm{SXT}^{2}$ : Sulfamethoxazole-trimethoprim, $\mathrm{CL}^{3}$ : Chlortetracycline ,FL ${ }^{4}$ : Florophenicol 


\section{VI- Association between bacterial and parasitic infection in ducks and fish}

Table 12: Bacterial infection associated with parasitic infection in examined ducks and fish.

\begin{tabular}{ccccc}
\hline Sources of isolates & $\begin{array}{c}\text { Bacterial } \\
\text { infection }\end{array}$ & $\begin{array}{c}\text { Parasitic } \\
\text { infection }\end{array}$ & $\begin{array}{c}\text { Mixed bacterial and } \\
\text { parasitic infection }\end{array}$ & Total \\
\hline Ducks & $8 / 100(8 \%)$ & $3 / 100(3 \%)$ & $61 / 100(61 \%)$ & $72 / 100(72 \%)$ \\
\hline Fish & $10 / 100(10 \%)$ & $16 / 100(16 \%)$ & $63 / 100(63 \%)$ & $89 / 100(89 \%)$ \\
\hline Total & $18 / 200(9 \%)$ & $19 / 200(9.5 \%)$ & $124 / 200(62 \%)$ & $161 / 200(80.5 \%)$ \\
\hline
\end{tabular}

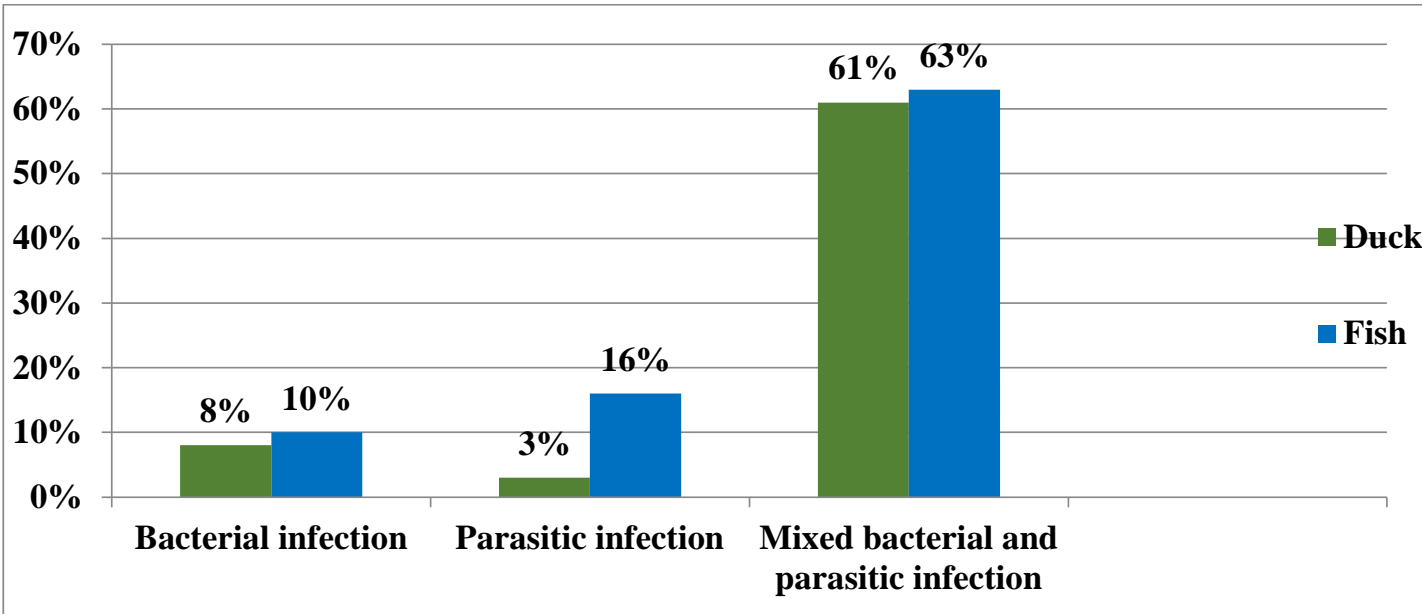

\section{Graph (3): Bacterial infection associated with parasitic infection in examined ducks and fish}

Cases of mixed bacterial and parasitic infections were detected with rates of 61/100 (61\%) and 63/100(63\%) of examined ducks, and fish, respectively. The results also revealed that $8 / 100(8 \%)$ and $10 / 100(10 \%)$ of examined ducks and fish suffered only form bacterial infections with no parasitic infestations. Moreover, parasitic infestations were isolated singly without bacterial infections in 3/100 (3\%) and 16/100(16\%) of examined ducks and fish, respectively, graph (3) and table (12).

\section{DISCUSSION}

A wide range of bacterial infections occur in freeranging birds. Such infections are regarded as important causes of morbidity and mortality (Davis et al., 1971, Steele and Galton, 1971). Egypt is considered the largest farmed tilapia producer in Africa and the second globally after China (FAO, 2013).

High prevalence rates of E.coli and Salmonella were recorded from birds thus clearly demonstrated poor hygiene and sanitary condition, (Adeyanju and Ishola, 2014). In the current study, the results of E.coli isolation revealed a total of 106/200 E.coli isolates with an overall prevalence rate of $(53 \%)$ among the total 200 studied ducks and fish, out of which 47/100 $(47 \%)$ isolates were isolated from household free range ducks. Higher prevalence rates were recorded by (Kissinga et al., 2018) who isolated E.coli from ducks with prevalence rate $(91 \%)$. In this regards,
(Roshdy et al., 2012) attributed the differences in prevalence rates of E. coli among cases of diarrhea and septicemia in ducks to the differences in the pathogenicity, virulence of involved strains, the severity of the cases and the immunological status of the host.

The result of E.coli isolation from fish recorded in the present study revealed that 59/100 (59\%) of examined Tilapia Zilli fish were infected with E.coli, this finding was in accordance with that of (Dutta, and Sengupta, 2016) who recorded a prevalence rate of (65\%) for E.coli from fish.

The current investigation revealed that the isolated E. coli belonged to eight serotypes of which four serotypes were isolated from ducks and fish as following, O26:H11, O17:H18 (25/106), O127 and O125: H21. Similar results for sero-identification of pathogenic E.coli serotypes (O125, O26, O146, O17, O127 and O153) were reported by (Wang et al., 2010 and Roshdy et al., 2012) who recorded the isolation of the mentioned serotypes from fish and from ducks, respectively. The results also were in agreement with that of (Gupta et al., 2013) who detected O17 and $\mathrm{O} 26$ in fish and ducks.

In the present study, bacteriological examination of a total of 200 examined ducks and fish revealed their infection by Salmoenella spp with a prevalence rate of $34 / 200(17 \%)$ of the examined ducks and fish, of which 25/100 (25\%) were isolated from ducks. These 
results were in agreement with the result of (Tran et al., 2006) who isolated Salmonella serovars from ducks with a prevalence rate of $(39.0 \%)$, while lower prevalence rate $(5.57 \%)$ for salmonella from cecal content of ducks was recorded by (Adzitey et al., 2012). The current result also revealed the isolation of salmonella spp from 9/100 (9\%) of examined Tilapia Zilli fish, higher prevalence rate was recorded by (Jeyasanta et al., 2012) who isolated salmonella with a prevalence rate of $(69 \%)$ from fish.

In the current study serotyping of the isolated Salmonella revealed that isolates belonged to eight serotypes of which 5/8 serotypes were isolated from ducks and fish as follows, Salmonella Enteritidis, Salmonella Saintpaul, Salmonella Anatum, Salmonella Typhimurium, and Salmonella Heidelberg. Similarly, the same serotypes were isolated by (Heinitz et al., 2000, Kumar et al., 2015) and by (Rahman et al., 2016 and Santosa et al., 2019) who reported their isolation from fish and ducks, respectively.

Öztürk and Altinok, (2014) concluded that Pseudomonas species are opportunistic pathogens as mostly are isolated with other bacteria, thus they suggested that Pseudomonas spp. can play the role of being secondary infections. In the present study, bacteriological examination, of Tilapia Zillii(fish) and backyard ducks revealed the isolation of 49/200 (24.5\%) strains of Pseudomonas spp, amongst 15/100 $(15 \%)$ isolates were isolated from ducks and 34/100 (34\%) isolates were isolated from Tilapia Zilli fish. These results agreed with that of (Aly et al., 2002) who isolated Pseudomonas spp. from ducklings with a prevalence rate of $(18 \%)$, while higher prevalence rate of pseudomonas species from fish was recorded by (Khalifa et al., 2016) who reported Pseudomonas aeruginosa with a prevalence rate $(43 \%)$ from Sea Bream fish. Lower prevalence rate was recorded by (Abd El-Tawab et al., 2016) who reported the isolation of pseudomonas species with a prevalence rate of (17\%) from fresh water fish.

In the present study, Pseudomonas fluorescens and Pseudomonas aeruginosa were detected form ducks and Tilapia zilli. This result was in agreement with that of (Aly et al., 2002) who detected Pseudomonas fluorescens from ducks and fish. The result also was in accordance with that of (Benie et al., 2017) who isolated Pseudomonas aeruginosa from fresh and smoked fish.

In the current study, bacteriological examination revealed the presence of mixed infection by Salmonella and E.coli in ducks and in fish with prevalence rates $(7 \%$ and $5 \%$ ), respectively, similar result was reported by (Sifuna and Onyango 2018) who found cases of mixed infection with Salmonella spp and E.coli in (82\%) of studied ducks and (7.3\%) of studied fish, respectively.
Isolation by conventional methods was confirmed by PCR for the detection of the relevant conserved genus or species genes in ten selected isolates from each of the studied bacterial species, the results revealed the positive detection of $16 \mathrm{~S}$ rRNA gene sequence, inv A gene (encodes for protein in the inner bacterial membrane and which is important for invasion of host epithelial cells by pathogenic salmonella species), and phoA gene (encodes for enzyme alkaline phosphatase in E.coli) in each 10/10 (100\%) of the tested isolates from Pseudomonas isolates, salmonella isolates, and E.coli, respectively. The results accorded with that of (Alagarsamy et al., 2009) who used PCR and confirmed the detection of (phoA gene) in all their tested E.coli isolates. The results also agreed with those of (Tekale et al., 2015) who targeted and detected (invA gene) to confirm all salmonella isolates, and (Khalifa et al., 2016) who detected (16S rRNA gene) in all Pseudomonas isolates.

Considering the studied helminthes; Clinostomum species, Echinostoma species, Ligula intestinalis and Contracaecum from ducks, the findings appear to indicate a host-parasite association as a part of the life cycle of these helminthes. Feeding animal reservoir hosts (dogs, cats, pigs, chicken, and ducks) with fish have been recorded as a risk factor for infection by zoonotic helminthes (Phan et al., 2010). Parasitic infections can affect a large number of fish species, especially in countries where untreated human and animal sewage and wastes may be drained into fish habitats without or with insufficient treatment, rendering the risk of potential fish-borne parasitic zoonosis quite large, particularly with important parasitic diseases as trematodes, nematodes, cestodes and protozoa, (Uddin et al., 2018).

In the present study, Clinostomum species was found with a total prevalence rate of 54/200 (27\%) from total 200 examined ducks and fish of which 15/100 (15\%) were isolated form ducks and 39/100 (39\%) were isolated from Tilapia zillii. In the same instances, six Clinostomum species were recognized in North America based on detailed morphological descriptions of stained and mounted adults recovered from avian hosts as recorded by (Caffara et al., 2011, Pe'rez-Ponce de Leo'n et al., 2016 and Rosser et al., 2017). Higher prevalence rates were recorded by (Taher, 2009) who recorded a total prevalence rate with one or more species of encysted metacercariae of $(84.75 \%)$, while the prevalence rate of microscopic encysted metacercariae and clinostomatid metacercariae were $(78.25 \%$ and $62.25 \%)$, respectively. Similar but slightly higher result was also recorded by (Arafa et al., 2005) who recorded (42.86\%) from fish, and (Abd-El- Rahman, 2005) who recorded a prevalence rate of (45\%) from ducks. Moreover, higher prevalence rate of Clinostomum 
species from fish was recorded by (Khattab, 1990) $(87.06 \%)$.

In the present study, Echinostoma species was isolated with a total prevalence rate of 30/200 (15\%) from examined ducks and fish of which 13/100 (13\%) was recorded from examined ducks (adults). In this regards, (Nagwa et al., 2013) recorded that (38\%) of studied ducks were infected with Echinostoma species, (Khater, 1993) recorded a prevalence rate of Echinostoma species infection in birds (47.4\%). Examination of fish revealed the isolation of Echinostoma species (metacercaria) from Tilapia zillii fish with a prevalence rate of $17 / 100$ (17\%), similar prevalence rate was recorded by (Tolossa and Tafesse, 2013) who recorded a prevalence rate of $(24.53 \%)$ from fish.

Fish-borne cestodes are capable of infecting birds. The members of the order Diphyllobothriidea, the large-sized tapeworms have three host life-cycles, in which fish play a role of the second intermediate hosts and represent a source of the infection (Chai et al., 2005).

In the present study, Ligula intestinalis larvae (cestode) was isolated with a total prevalence rate of $41 / 200(20.5 \%)$ of the total examined ducks and fish of which 19/100 (19\%) were isolated from ducks and 22/100 (22\%) were isolated from Tilapia zillii. These results nearly agreed with that reported by (Weliange and Amarasinghe 2001, Amer et al., 2007 and Woinishet and Anwar, 2014) who recorded prevalence rates of 39\%, $48 \%$ and $32 \%$ from Tilapia zillii, respectively. In the same regards, (Sohn et al., 2016) reported that the plerocercoid larvae of Ligula intestinalis recently caused mass fatality of fish in Korea. Hoole, (1994) concluded that Ligula intestinalis cestode have a strong host specificity for fish and birds, (Loot et al., 2001) concluded that Ligula intestinalis is an avian parasite but not a human parasite

Some nematodes have zoonotic significance, among these parasites, Contraceacum species larvae have the highest medical importance because of the severe allergic reactions and gastrointestinal symptoms they cause in the final hosts due to eating or handling infected fish (Lima-dos-Santos et al., 2011).

In the present study, Contraceacum species larvae was isolated with a total prevalence rate of 76/200 (38\%), of examined ducks and fish of which 30/100 $(30 \%)$ was isolated from examined ducks, higher prevalence rate was recorded by (Ansary et al., 2009) who recorded isolation of Contraceacum species larvae from ducks with a prevalence rate of $(65 \%)$. The current recorded prevalence rate of Contraceacum species larvae isolated from Tilapia zillii was $46 / 100(46 \%)$, while this result was in agreement with that of (Al-Moussawi and
Mohammad, 2011) who recorded a prevalence rate of $(59 \%)$ from Tilapia, higher prevalence rate was recorded by (Milad et al., 2013) who recorded a rate of $(71 \%)$ from Tilapia. Because the life-cycle of Contraceacum species larvae involving hosts at different level of the aquatic webs, Contraceacum species larvae parasites could be used as possible indicators of trophic web stability and health of aquatic ecosystems (Mattiucci and Nascetti, 2007).

Antimicrobial resistance has become a global concern in public health and veterinary medicine, high incidence of resistance might be attributed to the indiscriminate use of antibiotics (Szmolka and Nagy, 2013).

In the current study, the isolated E. coli, salmonella spp. and Pseudomonas spp demonstrated high phenotypic resistance patterns to neomycin with resistance rates of $(91.5 \%, 100 \%$ and $100 \%)$, respectively. Moreover, the studied E. coli, salmonella spp. and Pseudomonas spp isolates demonstrated resistance rates for Florfenicol (84.3\%, $85.3 \%$ and $89.8 \%$ ), respectively. The studied isolates of E. coli, salmonella spp and Pseudomonas spp also demonstrated phenotypic resistance to trimethoprimsulphamethoxine with rates of $(91.5 \%, 91.2 \%$ and $91.8 \%$ ), respectively. These results were similar to those of (Kissinga et al., 2018) who recorded high resistance rates of E.coli isolates from ducks to several antibiotic groups including cephalosporins aminoglycosides and tetracycline and (Alagarsamy et al., 2009) who recorded that their studied E.coli isolates demonstrated resistance to trimethoprimsulphamethoxine with a rate of $(62.3 \%)$. Similarly, (Cengizler et al., 2017) reported multidrug resistance phenotypes in aquaculture. Furthermore, (Skov et al., 2007) recorded that all their studied Salmonella isolates demonstrated multidrug resistance to Florfenicol, neomycin, trimethoprimsulphamethoxine, and chlortetracycline with rates of $(89 \%, 80 \%, 75 \%$, and $68 \%)$, respectively. In the same regards, (Khalifa et al., 2016) recorded that all Pseudomonas aeruginosa isolates were resistant to trimethoprim/ sulphamethoxazole, and florfenicol with resistance rates of ( $89 \%$ and $65 \%)$, respectively.

PCR was proven to be more sensitive and specific for detection of pathogens. In the current study PCR was applied to investigate the genotypic virulence attributes of the isolated salmonella spp. through detection of Salmonella enterotoxin (stn) gene, and the result revealed the detection of stn gene in the tested 10/10 (100\%) salmonella isolates. This result was in accordance with that of (Tekale et al., 2015) who found $(s t n)$ gene in all fish and ducks isolates. On the other hand, PCR failed to detect shiga-toxinproducing genes (stx 1 and st $x 2$ ) in the tested 10 E.coli isolates from ducks and Tilapia Zillii. The result was nearly in agreement with that of (Wang et al., 2010) who detected (stx 1 and st $x 2$ ) genes with a low 
detection rate $(2.4 \%)$ in E.coli isolates from ducks. In contrast, the recorded result disagreed with that of (Cardozo et al., 2018) who reported high detection rate of stx genes in E.coli isolates from fish.

Bacteria communicate with each other to coordinate expression of specific genes in a cell densitydependent fashion, a phenomenon called quorum sensing and response. Quorum sensing in Pseudomonas aeruginosa is a complex, multisignal, global regulatory network with control over diverse target functions including virulence factors, exoenzymes, motility, nutrient acquisition, and biofilm formation, two quorum sensing systems of LuxI-type proteins encoded at separate sites within the Pseudomonas aeruginosa genome for the transcriptional activators LasI and RhlI that regulate the virulence genes expression in Pseudomonas aeruginosa, (Clay Fuqua, 2006). In the current study, PCR was applied for the detection of lasI gene of pseudomonas species which is functioning as common regulatory feature and participate in specific ways in the infection process. Moreover, lasI gene may affect host cell signal transduction in ways that enhance the spread of infection, PCR was also applied to detect exotoxin (toxA) genes of pseudomonas species, the results revealed that $10 / 10$ $(100 \%)$ of the tested pseudomonas isolates which demonstrated phenotypic multidrug resistance were positive for both genes. These results accorded with those of (Markey et al., 2013) who detected toxA gene and lasI gene of Pseudomonas aeruginosa with rates of $(66.7 \%$ and $81 \%)$, respectively from Nile tilapia. The result also was in accordance with that of (Abd El -Tawab et al., 2016) who detected toxA gene and lasI gene with rates of $(67 \%$ and $88 \%)$, respectively from ducks.

PCR was applied for studying the antimicrobial genotypic attributes of isolates through the detection of florfenicol resistance gene floR, the antibiotic against which the isolates from different bacterial species have demonstrated the lowest phenotypic resistance rates, the results revealed that the tested 10/10 (100\%) E.coli, 10/10 (100\%) Salmonella spp. and 10/10 (100\%) Pseudomonas isolates were carriers for floR gene, similar result was recorded by (Abd El- Tawab et al., 2016) who detected floR gene in salmonella spp. isolated from ducks with a prevalence rate of $(77.8 \%)$ and (Smith, 2008) who detected floR gene in salmonella spp. isolated from fish. The results also accorded with that of (Keyes et al., 2000) who reported the detection of the florfenicol resistance gene flo R in E. coli isolates and (Nhung et al., 2017) who detected floR gene in Pseudomonas spp. isolates from birds.

Biofilm is defined as microbial communities attached to interfaces and to each other. In a biofilm, bacterial cells are embedded into a matrix forming a physicochemical barrier against different environmental conditions. Resistance to antimicrobial agents is the key feature of biofilm infections, thus, infections caused by bacterial biofilms are difficult to be treated. Moreover, biofilm formation was proven to enhance the multidrug resistance attributes of pathogens. In this regards, $a d r$ genes regulate cellulose production, consequently regulate biofilm formation in E.coli and salmonella spp (Rui et al., 2014). Moreover, psl, the polysaccharide synthesis gene cluster of pseudomonas, was recently identified as being involved in exopolysaccharide biosynthesis and biofilm formation, (Overhage et al., 2005). In this instance, (Bayoumi et al., 2012) concluded that pathogens may develop certain strategies to defy harsh conditions such as chemical sanitization, antibiotic treatment pressure, and biofilm formation which represents a prominent one among the adopted strategies, by which pathogens protect themselves against external threats.

In the current study testing the genetic attributes for biofilm formation was studied by PCR, the results revealed that $10 / 10(100 \%)$ of tested E.coli isolates and $10 / 10(100 \%)$ of tested salmonella spp. isolates were positive for (adrA) gene, and that 10/10 (100\%) of tested pseudomonas isolates were positive for (pslA) gene, these positive results for biofilm genetic attributes for all examined isolates were in association with the results of the phenotypic antimicrobial resistance profiles that revealed the phenotypic multidrug resistance attributes for 97/106 (91.5\%) of E. coli, $30 / 34(88 \%)$ of Salmonella spp. and 45/49 (91.8\%) pseudomonase spp involved in the study by demonstrating phenotypic resistance to antimicrobial agents from 3 and more antimicrobial categories as described by (CLSI, 2015). Similarly, (Hawash et al., 2017) reported the detection ( $a d r \mathrm{~A})$ gene encodes for biofilm formation in all salmonella isolated from cases of mixed infection in birds.

In the current study, mixed bacterial and parasitic infections were detected with prevalence rates of $61 / 100(61 \%)$ of examined ducks and $63 / 100(63 \%)$ of examined fish, these results agreed with the results of (Gomes et al., 2019) who detected a link between increased parasitic and bacterial infection in fresh water aquaculture with prevalence rate of $(56 \%)$. The result also agreed with that of (Hollmén and Franson, 2015) who found an association between bacterial and parasitic infection in ducks involved in their study.

Fish-eating birds not only acquire pathogens from environment, but also return them via excretion to the environment, facilitating the dissemination of those pathogens to humans and other animals, especially through water. Livestock on many farms rely on rivers, streams and other untreated water sources for at least part of their drinking water, (Reilly, 1981). 
Since many of the pathogens found in bird feces originate from human sewage, it's expected that humans will be most probably highly susceptible to infection when the bacteria or parasite re-enter the food chain through drinking water supplies and bathing water. Although all evidence concerning the life cycle and means of transmission of these helminthes have been obtained through experimentation, there is strong evidence that fish species are an important source of infection, as parasitic eggs fed by fish hatch in the intestine, and larvae from these fish have led to patent infections when reached birds, (Cross, 1990).

\section{CONCLUSION}

Free ranging ducks may represent an interface between aquaculture and terrestrial ecosystems for circulation and spreading of bacterial and parasitic pathogens that possessed virulence, antibiotic genotypic attributes and that some of which may also have zoonotic significance. Consequently, they may expose the environment including water resources, animals, fish, and humans to infection. Moreover, the high prevalence rates of bacterial and parasitic pathogens isolated from free range ducks and fish that share the same community and that are mutually exposed highlight the importance of conducting more investigations and studies on the implicated sources of infections, potential, association, and recommended control measures.

\section{REFERENCES}

Abd El Tawab, A.A.; Maarouf, A.A.A. and Ahmed, N.M.G. (2016): Detection of Virulence factors of Pseudomonas species isolated from fresh water fish by PCR. BENHA VET. Microbiol. J., VOL. 30, NO. 1: 199-207.

Abd-El-Rahman, A.M.M. (2005): Studies on prevailing parasitic diseases among some fresh water fishes caused by Digenetic trematodes SCVMJ, VIII (1) 13 ; 24.

Adeyanju, G.T. and Ishola, O. (2014): Salmonella and Escherichia coli contamination of poultry meat from a processing plant and retail markets in Ibadan, Oyo State, Nigeria. Springerplus, 3(1), 139.

Adzitey, F.; Rusul, G.; Huda, N.; Cogan, T. and Corry, J. (2012): Prevalence, antibiotic resistance and RAPD typing of Campylobacter species isolated from ducks, their rearing and processing environments in Penang, Malaysia. Int J Food Microbiol 2012, 154, 197-205.

Alagarsamy, S.; Thampuran, N. and Joseph, T.C. (2009): Virulence genes, serobiotypes and antibiotic resistance profile of Escherichia coli strains isolated from aquaculture and other sources. Aquaculture Research, $1^{\wedge} 12$.
Al-Moussawi, A.A. and Mohammad, K.M. (2011): Contracaecum rudolphii hartwich, 1964 (nematoda: anisakidae) in the cormorant phalacrocorax carbo (linnaeus, 1758) wintering in baghdad area: a new host record in Iraq, Bull. Iraq nat. Hist. Mus, 11 (3): 7-16.

Aly, S.M.; EL-Attar, A.A. and EL-Genaidy, H.M. (2002): Role of fish in transmission of Pseudomonas fluorescens to ducks with a trial for treatment and control (pathologic and electron microscopic studies). Sci. Cong. 2002, Fac. Vet. Med. Assiut Univ., Egypt.

Amer, O.H.; Ahmed, M.M. and Shagar, G.I.A. (2007): Studies on internal parasitic helminth diseases amoung wild Mediterranean sand smelt (Atherina) with special reference to Ligula intestinalis infection in Egypt, Egypt J. Aquat. Biol. \& fish, 11(3): 723-735.

Anh, N.T.L.; Madsen, H.; Dalsgaard, A.; Phuong, N.T.; Thanh, D.T.H. and Murrell, K.D. (2010): Poultry as reservoir hosts for fish-borne zoonotic trematodes in Vietnamese fish farms. Veterinary parasitology, 169(3-4), 391394.

Ansary, T.H.; Moghaddar, N. and Esmaeili, H.R. (2009): Iranocichla hormuzensis (Coad 1982), a new paratenic host of Contracaecum sp. and Phocanema sp. (Nematoda: Anisakidae), Comp Clin. Pathol., DOI 10.1007/s00580-0090872-1.

Aoki, T. (1999): Fish Diseases and Disorders, In Woo P.T.K. and Bruno D. (Eds.). CAB International U.K., USA.

Arafa, M.I.; Shaheen, M.S. and Monib, M.M. (2005): Studies on some clinostomatid metacercariae from Tilapia nilotica in Assiut Governorate. Assiut Vet. Med. J. 51. (107)218-227.

Bayoumi, M.A.; Kamal, R.M.; El-Aal, S.F.A. and Awad, E.I. (2012): Assessment of a regulatory sanitization process in Egyptian dairy plants in regard to the adherence of some food-borne pathogens and their biofilms. International Journal of Food Microbiology. 158(3): 225231.

Benie, C.K.D.; Nathalie, G.; Adjéhi, D.; Solange, A.; konan, K.; Desire, K.; Bourahima, B.; Marcellin, D.K. and Mireille, D. (2017): Prevalence and Antibiotic Resistance of Pseudomonas aeruginosa Isolated from Bovine Meat, Fresh Fish and Smoked Fish. Arch Clin Microbiol., 8:3.

Bhowmick, P.P.; Devegowda, D.; Ruwandeepika, H.A.D. Fuchs, T.M.; Srikumar, S.; Karunasagar, I. and Karunasagar, I. (2011): Gcpa (stm1987) is critical for cellulose production and biofilm formation on polystyrene surface by Salmonella enterica serovar Weltevreden in both high and low nutrient medium. Microbial Pathogenesis 50, 114-122. 
Bratu, S.; Gupta, J. and Quale, J. (2006): Expression of the las and rhl quorum-sensing systems in clinical isolates of Pseudomonas aeruginosa does not correlate with efflux pump expression or antimicrobial resistance. Journal of Antimicrobial Chemotherapy. 58, 1250-1253.

Bray, R.A.; Gibson, D.I. and Jones A. (2005): CAB International and the Natural History Museum, Keys to the trematoda, Vol 2.

Bunkley-Williams, L. and Williams, E.H. (1996): parasites of offshore big Game fishes of Puerto Rico and the Western Atlantic.

Caffara, M.; Locke, S.A.; Gustinelli, A.; Marcogliese, D.J. and Fioravanti, M.L. (2011): Morphological and molecular differentiation of Clinostomum sp. and Clinostomum marginatum (Digenea: Clinostomidae) metacercariae and adults. Journal of Parasitology, 97, 884-891.

Cardozo, M.V.; Clarissa, A.B.; Lívia, G.B.; Renato, P.M.; Alutab, A.S.P.; Mariana, M.B.; Luis, F.S.; Subhashinie, K.F. and Antônio, Á. (2018): Shigatoxigenic and atypical enteropathogenic Escherichia coli in fish for human consumption. Brazilian J. microbial., 4 9, 936-941.

Cengizler, I.; Aytaç, N. and Aldık, R. (2017): "Biocide use and its potential risks in aquaculture in Turkey." Eastern Anatolian Journal of Science, Vol. 3, No. 1, pp. 1-5.

Chai, J.Y.; Murrell, K.D. and Lymbery, A.J. (2005): Fish-borne parasitic zoonoses: status and issues. International Journal for Parasitology, 35: 1233-54.

Cheesbrough, M. (2000): Pseudomonas and related organisms. test to identify bacteria. Antibiotic susceptibility testing. In: District Laboratory Practice in tropical countries. Cambridge University Press, New York, USA, Pp. 19331943.

Clay Fuqua (2006): The QscR Quorum-Sensing Regulon of Pseudomonas aeruginosa: an Orphan Claims Its Identity. Journal of bacteriology, Vol. 188, No. 6, p. 3169-3171.

CLSI (2015): Performance Standards for Antimicrobial Susceptibility Testing; Twenty First Informational Supplement, M100S21, standard by Clinical and Laboratory Standards Institute.

Cross, J.H. (1990): Intestinal Capillariasis. Parasitol Today; 6: 26-8.

Davis, J.W.; ANDERSON, R.C.; Karstad, L. and Trainer, D.O. (1971): Infectious and parasitic diseases of wild birds. Ames, IA: Iowa State University Press.

Dipineto, L.; Santaniello, A.; Fontanella, M.; Lagos, K.; Fioretti, A. and Menna, L.F. (2006): Presence of Shiga toxin-producing Escherichia coli O157:H7 in living layer hens. Letters in Applied Microbiology 43, 293-295.
Doublet, B.; Lailler, R.; Meunier, D.; Brisabois, A.; Boyd, D.; Mulvey, M.R.; Chaslus-Dancla, E. and Cloeckaert, A. (2003): Variant Salmonella GenomicIsland 1 Antibiotic Resistance GeneCluster in Salmonella enteric Serovar Albany. Emerging Infectious Diseases - Vol. 9, No. 5: 585-591.

Dutta, C. and Sengupta, C. (2016): Prevalence of Escherichia coli in Fish and Shrimps obtained from Retail Fish Markets in \& around Kolkata, India. Frontiers in Environmental Microbiology, Vol. 2, No. 1, 2016, pp. 1-5.

FAO (2013): FAO Fisheries and Aquaculture Department has published the Global Aquaculture Production Statistics for the year 2011.

Ghadaksaz, A.; Fooladi; A.A.A.; Hosseini' H.H. and Amin, M. (2015): The prevalence of some Pseudomonas virulence genes related to biofilm formation and alginate production among clinical isolates. Journal of Applied Biomedicine, Volume 13, Issue 1, Pages 61-68.

Gomes, G.B.; Kate, S.H.; Jose, A.D.; SandraInfante, V.R.H.; Terrence, L.M. and Dean, R.J. (2019): Parasitic protozoan interactions with bacterial microbiome in a tropical fish farm. Aquaculture Volume 502, 15, Pages 196-201.

Gupta, B.; Ghatak, S. and Gill, J.P.S. (2013): Incidence and virulence properties of E. coli isolated from fresh fish and ready-to-eat fish products. Vetworld. 5-9.

Hawash, H.M.; El-Enbaawy, M.I.H. and Nasef, S.A. (2017): Biofilm producing non-typhoidal salmonella serovars field isolates screening from poultry farms. Bioscience Res., 14(4): 1050-1056.

Heinitz, M.L.; Ramona, D.; Ruble, D.E.; Wagner and Tatini, S.R. (2000): Incidence of Salmonella in Fish and Seafood. Journal of Food Protection, Vol. 63, No. 5, 579-592.

Hernandez, E.M.; Marquez, L.J.G. and OsorioSarabia, D. (1998): Gill lesions in common carp, Cyprinus caipo in Mexico due to the metacercariae of centrocestus formosanus. J. fish diseases, 21, p.229-232.

Hollmén, T.E. and Franson, J.C. (2015): Infectious diseases, parasites, and biological toxins in sea ducks. Ecology and conservation of North American sea ducks. Studies in Avian Biology, 46, 97-123.

Hoole, D. (1994): Tapeworm infection in fish: past and future problems in: Pike AW, ewis JW, editors. Parasitic Diseases of fish.Tresaith: Samara publishing Limited, pp.119-140.

$H u, Q . ; T u, J . ; H a n, X$.; Zhu, Y.; Ding, C. and $Y u, S$. (2011): Development of multiplex PCR assay for rapid detection of Riemerellaanatipestifer, Escherichia coli, and Salmonella enterica simultaneously from ducks. Journal of Microbiological Methods 87 (2011) 64-69. 
Hurlbert1, A.H.; Anderson, T.W.; Sturm, K.K. and Hurlbert, S.H. (2007): Fish and fish-eating birds at the Salton Sea: a century of boom and bust. Lake and Reservoir Management 23: 469-499.

ISO/IEC 6579-1:2017(en): Microbiology of the food chain - Horizontal method for the detection, enumeration and serotyping of Salmonella Part 1: Detection of Salmonella spp.

Jeyasanta, K.I.; Aiyamperumal, V. and Patterson, J. (2012): Prevalence of Antibiotic resistant Escherichia coli in Seafood of Tuticorin coast, Southeastern India. Advances in Biological Research, 6(2) pp 70-77.

Keyes, K.; Charlene, H.; John, J.; Maurer, S.T.; David, G.W. and Margie, D.L. (2000): Detection of Florfenicol Resistance Genes in Escherichia coli Isolated from Sick Chickens. Antimicrobial agents and chemotherapy, p. 421-424.

Khalifa, E.; Khallaf, M. and Hashem, M. (2016): Molecular Study on some Virulence and Fluoroquinolone Resistance Genes of Pseudomonas aeruginosa Isolated from Naturally Infected Cultured Sea Bream Fish (Sparus aurata) in Egypt. J Infect Dis Preve Med, 4:2

Khater, H.F. (1993): Studies on enteric helminthes parasites in domestic birds M.V.sc, thesis, Fac. vet. Med. Benha Zagasig univ.

Khattab, M.H. (1990): Some studies on Platyhelminthes infesting some freshwater fishes in Egypt M.V.Sc Thesis, Fac. of Vet. Med., Alex. Univ.

Kissinga, H.D.; Mwombeki, F.; Said, K.; Abdul, A.S.; Katakwebal, H.E.N. and Amandus, P.M. (2018): Antibiotic susceptibilities of indicator bacteria Escherichia coli and Enterococci spp. isolated from ducks in Morogoro Municipality, Tanzania. BMC Res Notes, 11: 87.

Kreig, N.R.; Holt; J.G. and Wil-kins, W. (1984): Bergeys Manual of Systematic Bacteriol., 1:428, East Preston street, Balti-mor, M.D. 21202, USA.

Kumar, R.; Tirtha, K.D. and Kuttanappilly, V.L. (2015): Salmonella grows vigorously on seafood and expresses its virulence and stress genes at different temperature exposure. BMC Microbiology., 15: 254.

Lima-dos-Santos, CAM. and Howgate, P. (2011): Fishborne zoonotic parasites and. aquaculture: A review. Aquaculture, 318:253-61.

Loot, G.; Lek, S. and Gue, J.F. (2001): Phenotypic modification of roach (Rutilus rutilus) infected with ligula intestinalis (cestoda, pseudophylidea). J. Parasitol., 87: 1002-1010.

Lucky, Z. (1977): Methods for diagnosis of fish diseases. Amerind publishing Co. New Delhi, India.
MacFaddin, J.F. (2000): Biochemical tests for identification medical bacteria. Warery Press Inc, Baltimore, Md. 21202 USA.

Markey, B.K.; Leonard, F.C.; Archambault, M.; Cullinane, A. and Maguire, D. (2013): Clinical Veterinary Microbiology. 2nd Ed. MOSBY. Elsevier Ltd. Edinburgh London New York Oxford Philadelphia St Louis Sydney Toronto.

Matar, G.M.; Ramlawi, F.; Hijazi, N.; Khneisser, I. and Abdelnoor, A.M. (2002): Transcription Levels of Pseudomonas aeruginosaExotoxin A Gene and Severity of Symptoms in Patients with Otitis Externa. CURRENT MICROBIOLOGY Vol. 45 (2002), pp. 350354.

Mattiucci, S. and Nascetti, G. (2007): Genetic diversity and infection levels of anisakid nematodes parasitic in fish and marine mammals from Boreal and Austral hemispheres. Vet. Parasitol, 148: 43-57.

Milad, A.; Hamid, R.A. and Amin, N. (2013): Scomberomorus Commerson, a New Paratenic Host of Contracaecum sp. and Anisakis sp. (Nematoda: Anisakidae) from Persian Gulf, World Journal of Fish and Marine Sciences 5 (3): 310-314.

Murugkar, H.V.; Rahman, H. and Dutta, P.K. (2003): Distribution of virulence genes in Salmonella serovars isolated from man $\&$ animals. Indian J Med Res., 117: 66-70.

Nagwa, E.A.; Loubna, M.A.; El-Madawy, R.S. and Toulan, E.I. (2013): Studies on helminths of poultry in Gharbia Governorate. Benha Vet. Med. J, 25(2), 139-144.

Nhung, N.T.; Chansiripornchai, N. and CarriqueMas, J.J. (2017): Antimicrobial Resistance in Bacterial Poultry Pathogens: A Review. Front. Vet. Sci. 4:126.

Olivera, S.D.; Rodenbusch, C.R.; Ce, M.C.; Rocha, S.L.S. and Canal, C.W. (2003): Evaluation of selective and non selective en-richment PCR procedures for Salmonella de-tection. Lett. Appl. Microbiol., 36: 217-221.

Overhage, J.; Schemionek, M.; Webb, J.S. and Rehm, B.H. (2005): Expression of the psl operon in Pseudomonas aeruginosa PAO1 biofilms: PslA performs an essential function in biofilm formation. Appl Environ Microbiol. ; 71(8): 4407-13

Öztürk, R.Ç. and Altınok, I. (2014): Bacterial and Viral Fish Diseases in Turkey. Turkish Journal of fisheries and Aquatic Sciences 14: 275-297.

Patrick, A.D.; Grimont and Francois-Xavier Eeill, (2007): Antigenic formulae of the salmonella serovars, 9th edition, WHO collaborating centre for Reference and research on Salmonella.

Pe'rez-Ponce De Leo'n, G.; Garci'a-Varela, M.; Pinacho-Pinacho, C.D.; Sereno-Uribe, A.L. and Poulin, R. (2016): Species delimitation in 
trematodes using DNA sequence: MiddleAmerican Clinostomum as a case study. Parasitology, 143, 1773-1789.

Phan, V.T.; Ersbøll, A.K.; Nguyen, K.V., Madsen, H. and Dalsgaard, A. (2010): Farm-Level Risk Factors for Fish-Borne Zoonotic Trematode Infection in Integrated Small-Scale Fish Farms in Northern Vietnam. PLoS Neglected Tropical Diseases 4(7): 1-9.

Quinn, P.J.; Carter; M.E., Markey, B. and Carter, G.R. (1994): Listeria species. In: P.J. Quinn, M.E. Carter, B. Markey and G.R. Carter (eds.), Clinical Veterinary Microbiology. Mosby International Limited, London.

Rahman, M.; Mirza, M.M.; Shafiqul, I.K. and Mostafa, A.K.M. (2016): Isolation and antibiogram of Salmonella spp. from duck and pigeon in Dinajpur, Bangladesh. Journal of Advanced Veterinary and Animal Research., ISSN 2311-7710, Vol 3 No 4, Pages 386-391.

Reilly, W.J. (1981): Human and animal salmonellosis in Scotland associated with environmental contamination, 1973-79. The Veterinary Record 108, 553-555.

Roshdy, H.; Abd El-Aziz, S. and Refai, M. (2012): Incidence of $E$. coli in chickens and ducks in different governorates in Egypt. 1st Conf. of An. Health Res. Inst. Assoc. pp. 420-426.

Rosser, T.G.; Alberson, N.R.; Woodyard, E.T.; Cunningham, F.L.; Pote, L.M. and Griffin, M.J. (2017): Clinostomum album n. sp. and Clinostomum marginatum (Rudolphi, 1819), parasites of the great egret Ardea alba L. from Mississippi. USA. Systematic Parasitology, 94, 35-49.

Rui, S.; Jorge, M.; Fernando, B.; Cristina, V. and Manuela, O. (2014): Biofilm Formation by Salmonella Enterica Serovar 1,4,[5],12:i:Portuguese Isolates: A Phenotypic, Genotypic, and Socio-geographic Analysis. Current Microbiology. January 2014. DOI 10.1007/ s00284-014-0523-x.

Santosa, R.R.; Xaviera, R.G.C.; Ferreirade, O.; Cerqueira, L.H.; Cesar, P.F. and Augusto, G.L. (2019): Occurrence, genetic diversity, and control of Salmonella enterica in native Brazilian farmed fish. Aquaculture. 11.034

Sifuna, A.W. and Onyango, D.M. (2018): Source Attribution of Salmonella and Escherichia coli Contaminating Lake Victoria fish in Kenya. African Journal of Tropical Hydrobiology and Fisheries 16: 39-47.

Skov, M.N.; Strodl, A.J.; Søren, A.; Steen, E.; Frank, M.A.; Anders, H.; Gitte, S.; Kar, P.; Steen, N.; Katharina, E.P.; Peter, G. and Dorte, L.B. (2007): Antimicrobial Drug Resistance of Salmonella Isolates from Meat and Humans, Denmark. Emerging Infectious Diseases., Vol. 13 , No. 4

Smith, P. (2008): Aquaculture and Florfenicol Resistance in Salmonella enterica
Typhimurium DT104. Emerg Infect Dis.; 14(8): 1327-1328.

Sohn, W.M.; Na, B.K.; Jung, S.G. and Kim, K.H. (2016): Mass death of predatory carp, Chanodichthys erythropterus, induced by plerocercoid larvae of Ligula intestinalis (Cestoda: Diphyllobothriidae). The Korean journal of parasitology, 54(3), 363.

Spilker, T.; Coenye, T.; Vandamme, P. and LiPuma, J.J. (2004): PCR-Based Assay for Differentiation of Pseudomonas aeruginosa from Other Pseudomonas Species Recovered from Cystic Fibrosis Patients. J. Clinical microbial., p. 2074-2079.

Steele, J.H. and Galton, M.M. (1971): Salmonellosis. In: Davis, J.W., Anderson, R.C., Karstad, L. \& Trainer, D.O. (Eds). Infectious and parasitic diseases of wild birds. Ames, IA: Iowa State University Press. pp. 51-58.

Sugita H.; Nakamura T.; Tanaka K. and Deguchi Y. (1994): Identification of Aeromonas species isolated from freshwater fish with the microplate hybridization method. Applied and Environmental Microbiology, 66: 3036-3038.

Szmolka, A. and Nagy, B. (2013): Multidrug resistant commensal Escherichia coli in animals and its impact for public health. Front Microbiol., 4: 258270.

Taher, G.A. (2009): Some studies on metacercarial infection in Oreochromis niloticus in Assiut Governorate and their role in transmission of some trematodes to dogs. Assiut University Bulletin for Environmental Researches, 12(1), 63-79.

Tekale, A.A.; Savalia, C.V.; Kshirsagar, D.P.; Brahmbhatt, M.N. and Chatur, Y.A. (2015): Detection and Virulence Gene Characterization of Salmonella Isolates from Fish by Conventional and Molecular Methods. J. Vet. Pub. Hlth., 13 (1): 43-46

Tolossa, Y.H. and Tafesse, H.A. (2013): Occurance of ecto parasites and gastrointestinal helminthes infection in Fayomi chickens (Gallus gallus Fayomi) in debre Zeit Agriculture research centre poultry farm, Oromia region Ethiopia. Journal of veterinary medicine and animal health.5 (4): 107-112.

Tran, T.H.; Nguyen, T.T.; Hoang, Q.T.; Le, T.T.; Lam, M.T. and Nguyen, T.H.L. (2006): Prevalence of Salmonella spp. in poultry in Vietnam. Ann N Y. Acad Sci 1081, 266-268.

Uddin, S.; Sarker, S.C. and Mondal, D.K. (2018): Health risk from contaminated aquaculture fish. International Journal of Natural and Social Sciences, 5(2): 01-16.

Vernon, E.T. (2006): Aquatic Biodiversity in Latin America, Amazon Fish Parasites, Volume 1.

Wang, Y.; Tang, C.; Yu, X.; Xia, M. and Yue, H. (2010): Distribution of serotypes and virulence-associated genes in pathogenic 
Escherichia coli isolated from ducks. Avian Pathology., 39(4), 297-302

Weliange, W.S. and Amarasinghe, U.S. (2001): The Occurrence of Cestode Ligula intestinalis (Linnaeus) from Attentive Carplet Amblypharyngodon melettinus (Valenciennes) in Sri Lanka, Asian Fisheries Science 14: 9599.
Woinishet, D. and Anwar, N. (2014): Ligula intestinalis plerocercoid infection in large Barbus fish (Barbus intermedius complex) from tributaries of Lake Tana, Ethiopia, Livestock Research for Rural Development 26 (5).

\section{البط المنزلى الحر ، نظرة عامة على المسبيات البكتيرية والطفيلية للعدوى المعوية سماح عيد ، سارة عطية عبد المنعم ، أمل سعبل العكش \\ E-mail: saidamal19@yahoo.com Assiut University web-site: www.aun.edu.eg}

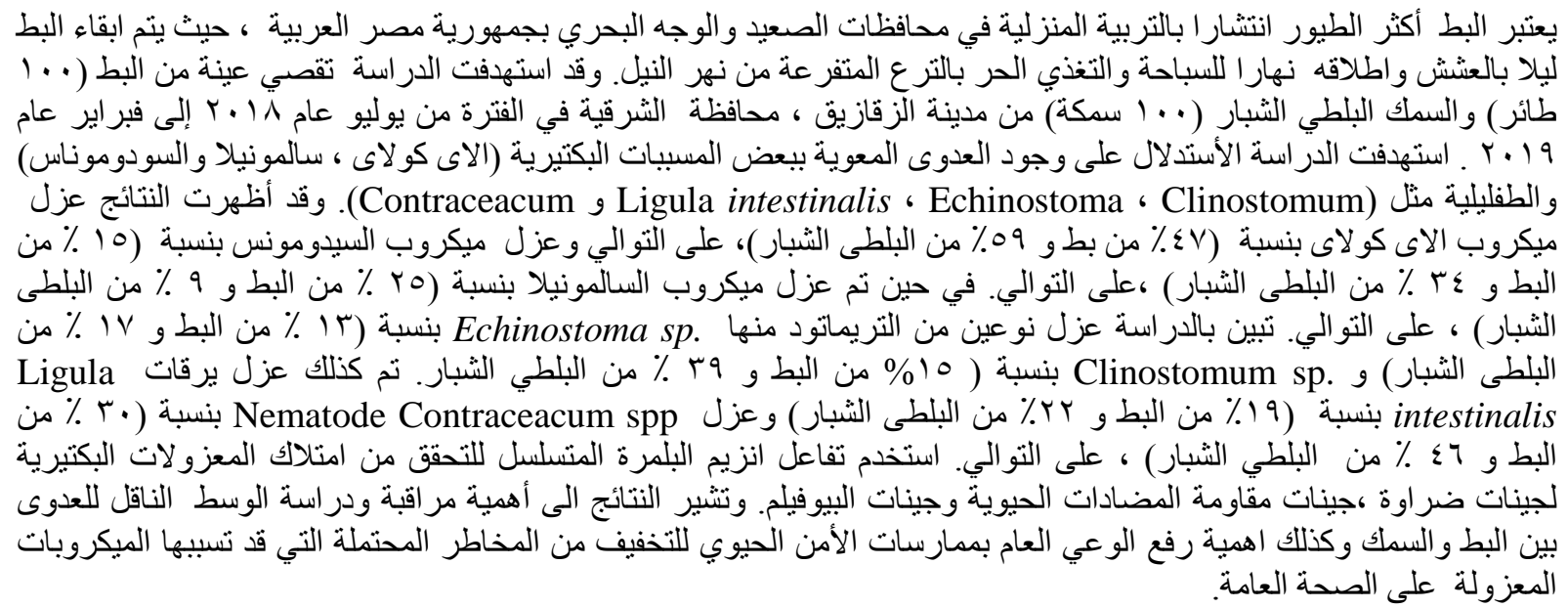

